\title{
Tertiary development of the Faeroe-Rockall Plateau based on reflection seismic data
}

\author{
LARS OLE BOLDREEL \& MORTEN SPARRE ANDERSEN
}

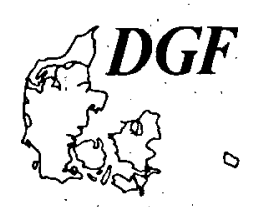

Boldreel, L.O. \& Andersen, M.S.: Tertiary development of the Faeroe-Rockall Plateau based on
reflections seismic data. Bulletin of the Geological Society of Denmark, Vol. 41, pp.
162-180. Copenhagen, 1994-11-30. https://doi.org/10.37570/bgsd-1995-41-15

The Faeroe-Rockall Plateau is located in the NE Atlantic Ocean between Iceland and Scotland and is characterized by a late Paleocene-early Eocene basalt cover, which was extruded in association with the incipient opening of the NE Atlantic. The Faeroe-Rockall Plateau is separated from the NW European continental shelf by the Rockall Trough and the FaeroeShetland Channel, whose nature and age is still debated. Reflector configuration within the basalt allows volcanic seismic facies interpretation to be carried out. The thickness of the basalt cover is estimated from reflection seismic data. Subbasalt geological structures are identified below subaerially extruded basalt on recently acquired as well as reprocessed seismic profiles. Overlying the basalt are early Eocene and younger sediments. The distribution of these sediments is largely controlled by 1) the topography after the cessation of the volcanism, 2) the post volcanic subsidence of the area which is estimated from the depth to the breakpoints located on primary volcanic escarpments, 3 ) the Eocene-Miocene compressional tectonics which formed ridges and minor basins, and 4) bottom currents of Norwegian Sea Deep Water (NSDW) which in the Neogene flowed into the North Atlantic south of the Greenland-Iceland-Faeroe-Scotland Ridge. A considerable part of the NSDW flows east and south of the Faeroes and are controlled by the subsided volcanic basement and compressional structures.

L.O. Boldreel \& M.S. Andersen, Geological Survey of Denmark, Thoravej 8, DK-2400 København NV, Denmark. June 11th 1994.

\section{Introduction}

The Faeroe-Rockall Plateau (Fig. 1), located in the NEAtlantic Ocean between Iceland and Scotland, was formed during the rifting activity along the North Atlantic Margin which concluded with the opening of the NE-Atlantic Ocean. Thus the Faeroe-Rockall Plateau may be considered part of the NE-Atlantic volcanic passive margin. The Faeroe-Rockall Plateau is characterized by mainly subaerial extruded plateau basalt of Paleoceneearly Eocene age (Rasmussen \& Noe-Nygaard 1969, 1970, Laughton, Bergren et al. 1972, Roberts, Bott \& Uruski 1983, Smythe 1983, Roberts, Schnitker et al. 1984, Wood, Hall \& van Hom 1987, Prægel \& Waagstein 1988, Waagstein 1988). It is assumed that the early Tertiary volcanic activity of the NE-Atlantic passive margin is associated with lithospheric extension (late Cretaceousearly Tertiary) preceding the early Tertiary (late Paleocene-early Eocene) continental break-up between the Faeroe-Rockall Plateau and Greenland (e.g. Smythe 1983, Roberts, Backman, Morton, Murry, \& Keene 1984a, Mudge \& Rashid 1986, Hitchen \& Ritchie 1987). Recently it has been suggested that the large amount of volcanic products on the NE Atlantic margins and other passive margins compared to rifted continental margins is caused by increased lithospheric heatflow as the result of hot mantle-plumes - in the case of the NE Atlantic margins, the Iceland mantle plume (White, Spence, Fowler, McKenzie, Westbrook \& Bowen 1987, White 1988, McKenzie \& Bickle 1988).

Subbasalt geological information is sparse as drilling has not succeded in penetrating the basalt and as the basalt is mostly an obstacle to seismic investigations.

In this paper, which is based on regional multi channel reflection seismic data, the regional setting of the FaeroeRockall Plateau is introduced. The seismic character of the basaltic succession and the subbasalt geology is briefly discussed. Then four factors which to a large extent control the distribution of the Tertiary sediments above the surface of the basalt on the- Faeroe-Rockall Plateau are outlined: subsidence of the Faeroe-Rockall Plateau, primary morphology of the surface of the basalt, compressional structures in the area and contour current deposits (and erosion) in the Faeroe Channels gateway east and south of the Faeroes.

Bulletin of the Geological Society of Denmark 


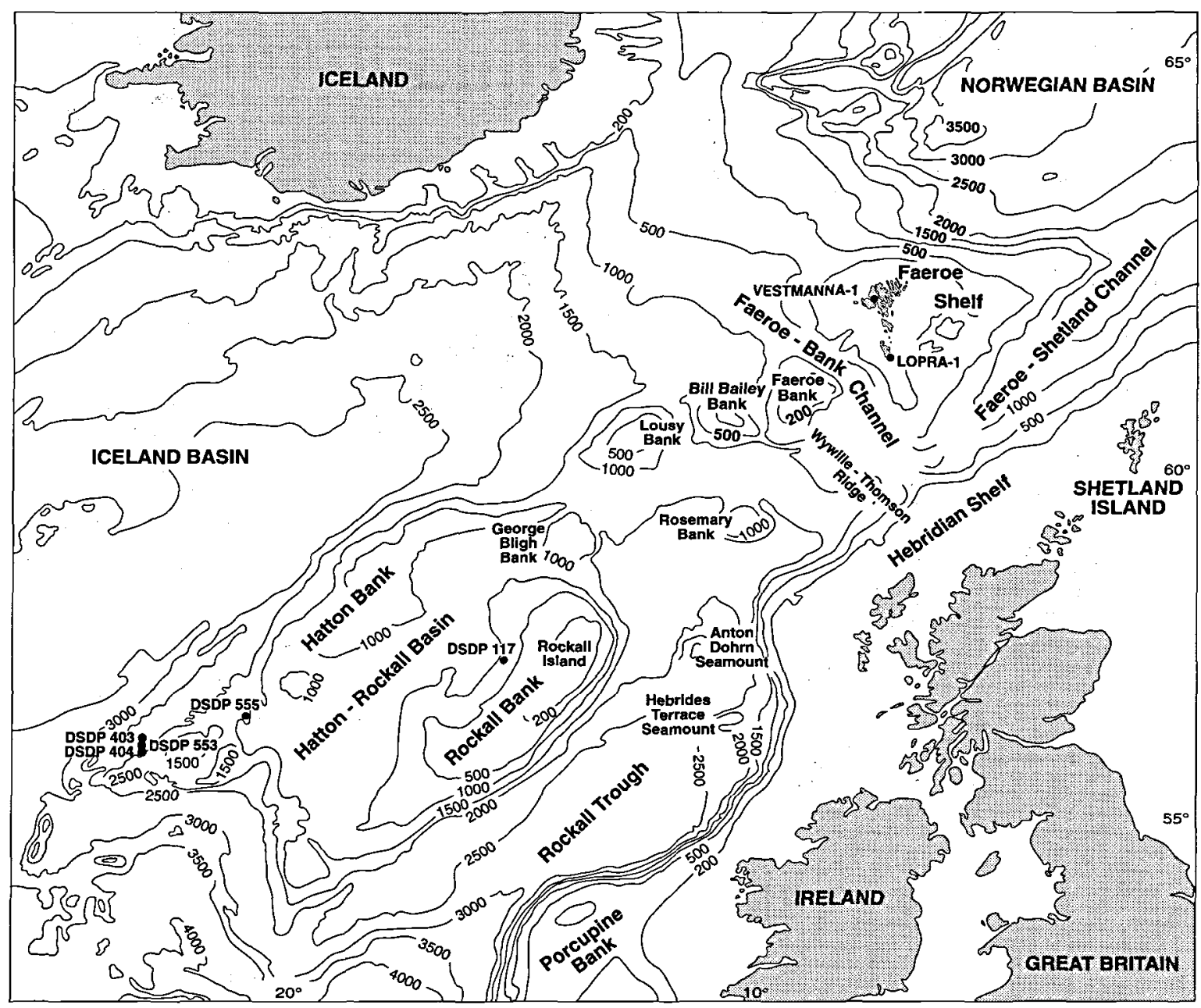

Fig. 1. Batymetric map of the Faeroe-Rockall Plateau and surroundings. Deep wells on the Faeroe Islands and selected DSDP wells are marked.

\section{Regional geological framework}

Samples of Precambrian rock outcropping on the seafloor (Miller \& Mathews 1973, Roberts, Ardus \& Dearnley 1973), geochemical analysis of the plateau basalt (Gariepy, Ludden \& Brooks 1983; Hald \& Waagstein 1983) and geophysical investigations (e.g. Scrutton 1972, Bott, Nielsen \& Sunderland 1976, White et al. 1987, Makris, Ginzburg, Shannon, Jacob, Bean \& Vogt 1991, Neish 1993) all indicate that the Faeroe-Rockall Plateau is underlain by continental crust. Tertiary oceanic crust is located to the north and to the west of the Faeroe-Rockall Plateau (Fig. 2) and has been formed since magnetic chron C24 (Nunns 1983), the early Eocene. Large wedges of mainly sub-aerially erupted basalts, the seaward dipping reflectors (SDR) (Hinz 1981), are found at the approximate location of the continent to ocean transition (COT)(Smythe 1983, Roberts, Morton \& Backman 1984b, Spence, White, Westbrook \& Fowler 1989). The exact location of the COT in relation to the SDR has been debated (e.g. Talwani, Mutter \& Hinz 1983) as is the mechanism responsible for the formation of the SDR (Smythe 1983, Roberts 1984, Mutter \& Zehnder 1988, Skogseid and Eldholm 1988, White 1988, Eldholm, Thiede, Taylor et al: 1987). Based on conversion of seismic P-waves northwest of the Faeroes, the COT is here located below the inner part of the SDR (Fig. 2, Bott et al. 1976).

The Faeroe-Rockall Plateau is separated from the NW European continental shelf by the Rockall Trough and the Faeroe-Shetland Channel which constitutes a major Tertiary Basin (Fig. 1). The origin and age of the FaeroeShetland Channel and the Rockall Trough is still debated. Plate tectonic reconstructions, crustal thickness and the lack of faultblocks dipping away from the margin, as well as a seismic anisotropic upper mantle between the Fae- 


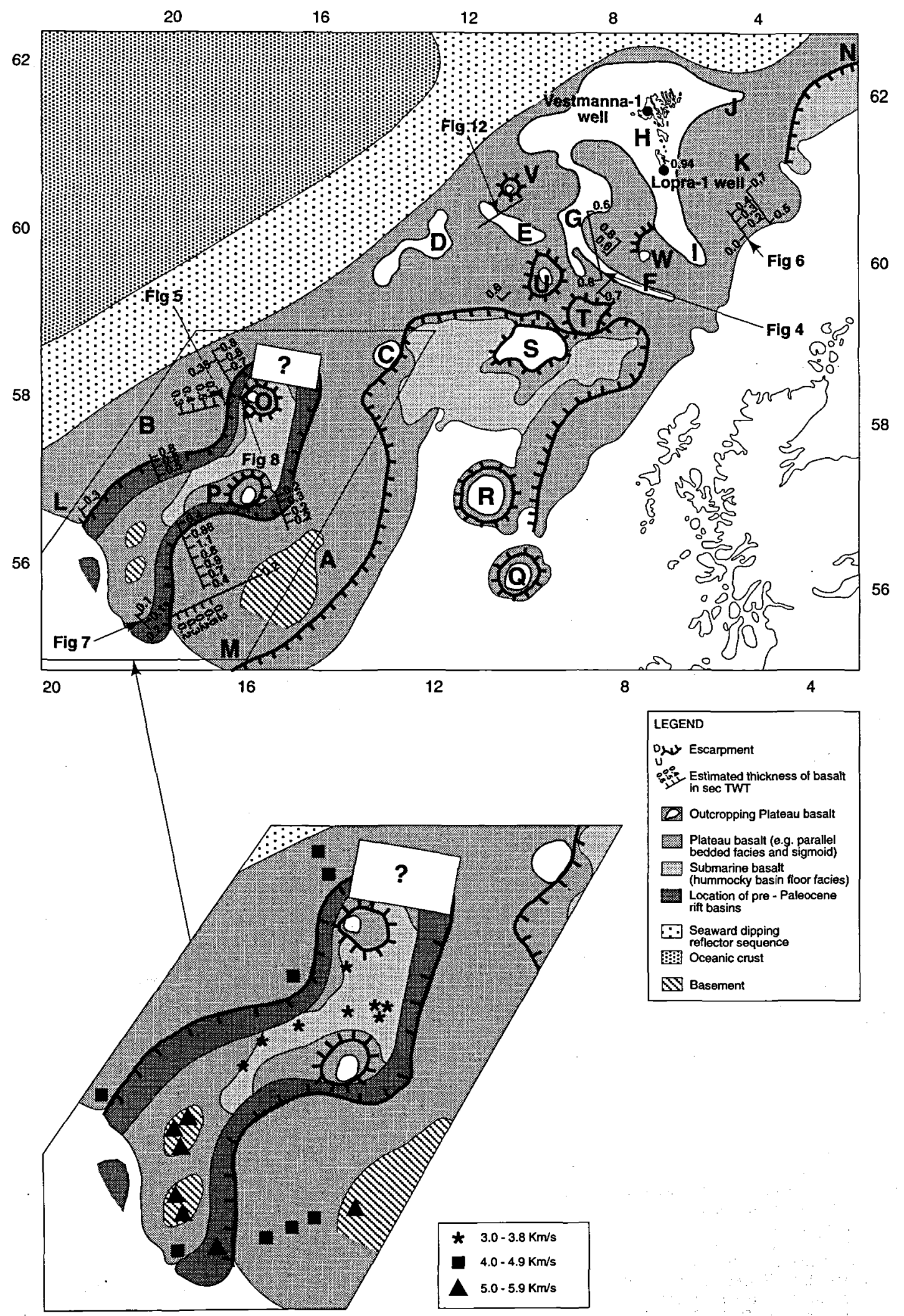



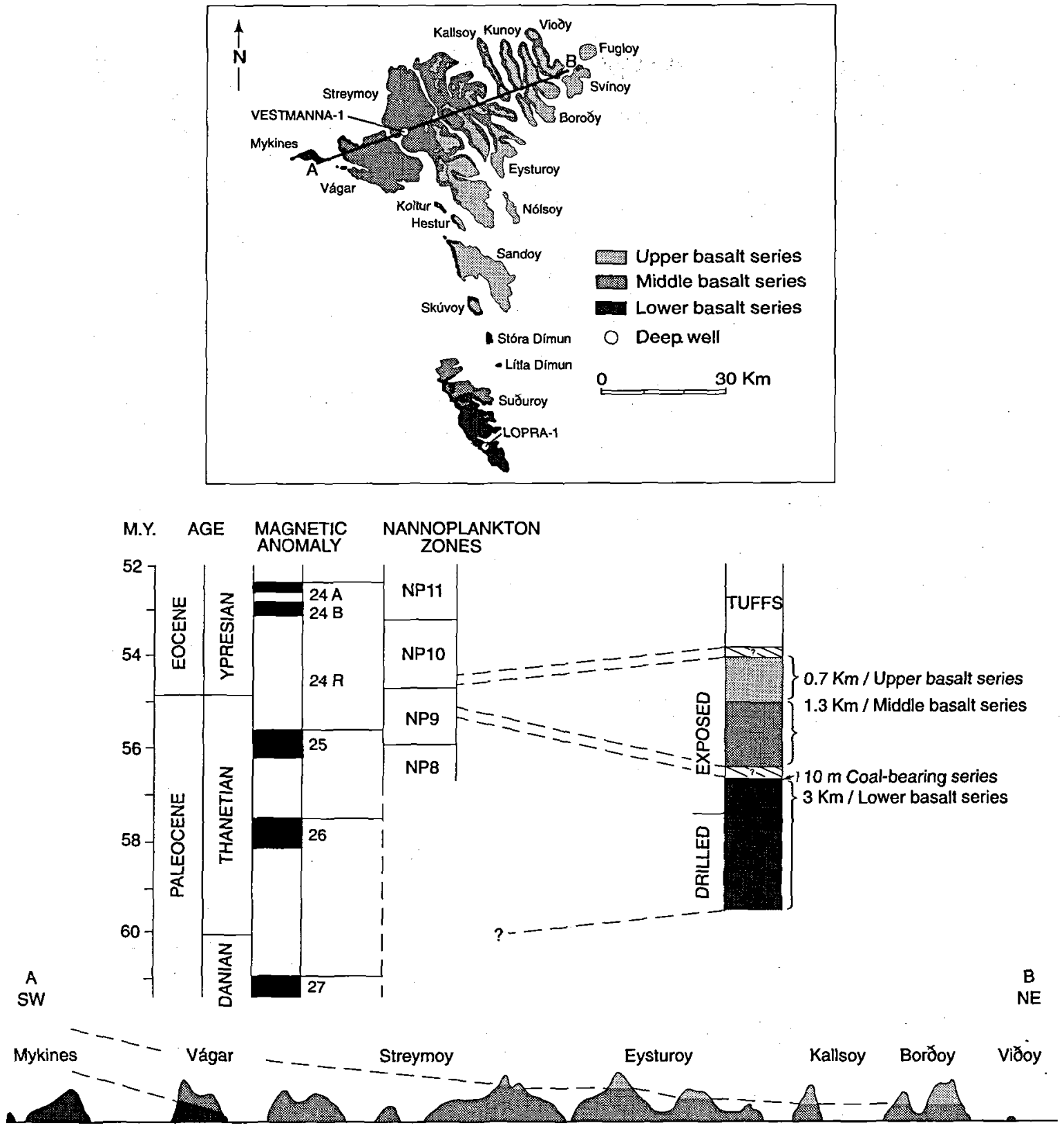

Fig. 3. Stratigraphical relation of the three Basalt Series on the Faeroe Islands. Below an east-west cross section of the Faeroe Island group.

Fig. 2. Regional geology of the Faeroe-Rockall Plateau and surroundings showing the locations of the different basalt types, the regional primary volcanic escarpments, and the local primary volcanic escarpments. Also shown is the thickness of the basalt cover, figure location and selected names of geologic structures. Inserted is the velocity analysis obtained from the seismic experiment (Andersen et al. 1990).

A, Rockall Bank; B, Hatton Bank; C, Georges Bligh Bank; D, Lousy Bank; E, Bill Bailey Bank; F, Wyville-Thomson Ridge Complex; G, Faeroe Bank; H, Faeroe Platform; I, Munkagrunnar Ridge; J, Fugloy Ridge; K, East Faeroe High; L, Hatton-Rockall Basin Escarpment; M, Rockall Escarpment; N, Faeroe-Shetland Escarpment; O, Mammal Seamount; P, East Hatton-Rockall Basin Seamount; Q, Hebrides Terrace Seamount; R, Anton Dohrn Seamount; S, Rosemary Bank; T, Darwin Seamount; U, Sigmundur Seamount; V, North Bill Bailey Bank Seamount. 


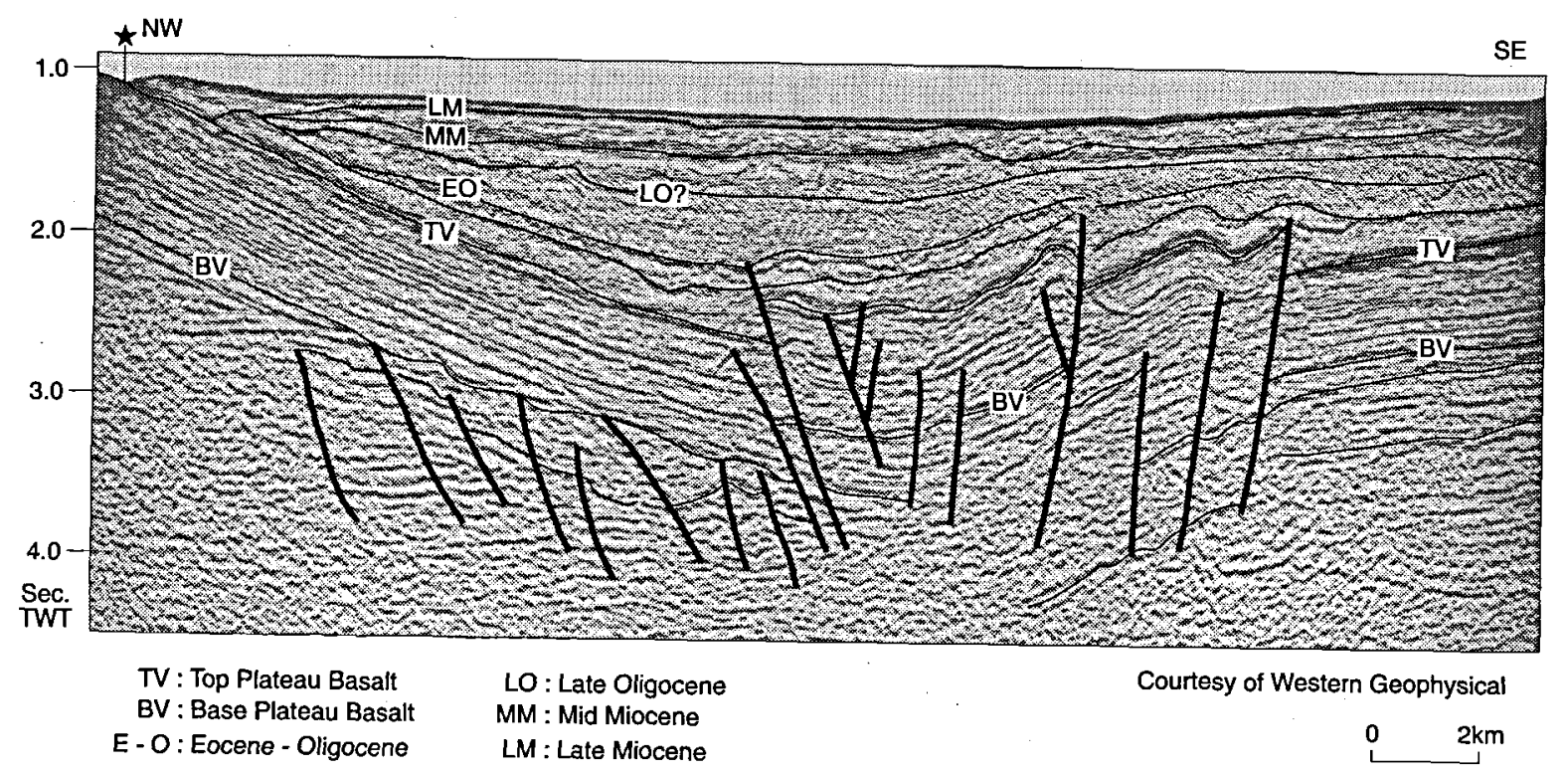

Fig. 4. Reprocessed multi-channel reflection seismic profile showing part of a compressional ridge: the Wyville-Thomson Ridge and the faulting occuring in the basin located between the Wyville-Thomson Ridge (to the left) and the Ymir Ridge (outside the figure to the southeast). Note parallel bedding of basalt, pre-basalt geology and faulting of basalt and younger sequences. Permission to
publish from Western Geophysical.

roes and the Shetlands, suggest that the Rockall Trough (Hazeldine 1984) and probably the Faeroe-Shetland Channel have been formed as a result of seafloor spreading (Bott 1984, Hanisch 1984). However, the observation of a mid-crustal reflector, the seismic velocities and the lack of linear magnetic patterns suggests that the FaeroeShetland Channel and Rockall Trough were created by rifting of continental crust (Roberts, Ginzburg, Nunn \& McQuillin 1988, Neish 1993). However, Joppen \& White (1990) suggest that the observed seismic velocities indicate that oceanic crust is present below a part of the Rockall Trough and advocate a more complex origin of the Rockall Trough involving both rifting and seafloor spreading.

\section{Basalt series on the Faeroe Islands}

The Faeroe Islands consits of Plateau basalt. The basalt is divided into three series: the Lower, the Middle and the Upper Basalt Series which all were erupted subaerially (Fig. 3). The series have been studied by extensive fieldwork and by the two deep wells Vestmanna-1 and Lopra-1, drilled in 1980-81 (see for example Rasmussen \& Noe-Nygaard 1970, Bertelsen, Noe-Nygaard \& Rasmussen 1984, Waagstein 1988). The oldest volcanics are represented by the Lower Basalt Series. It has been suggested, that it was extruded in the Thanetian during chrons C26R to C25N (Waagstein 1988). At the $2.2 \mathrm{~km}$ deep Lopra-1 well site the lower series had an original thickness of at least $3000 \mathrm{~m}$ (Hald \& Waagstein 1984,
Jørgensen 1984) and probably less than $3500 \mathrm{~m}$ (Kiørboe \& Petersen 1992). The series consists of 20-50 m thick parallel bedded subaerial flows with minor intercalations of tuff and volcaniclastic sediments and is characterized by rythmic fissure eruption (Rasmussen \& Noe-Nygaard 1970).

Following the formation of the Lower Basalt Series there was a period of volcanic quiescence. This is expressed by the coal bearing sequence which consists of approximately $10 \mathrm{~m}$ of lacustrine sediments containing allocthonous coal beds of late Thanetian age (Fig. 3, Lund 1981, 1984), magnetic chron C24R (Waagstein 1988). The extrusion of the Middle and Upper Basalt Series, found above the coal bearing sequence, is suggested to have taken place during C24R also (Waagstein 1988).

The middle basalt series is approximately $1.4 \mathrm{~km}$ thick consisting of rather thin flows, especially in the lower part, generally up to a few meters thick. The volcanism formed very flat shield volcanoes over parts of the old fissures (Noe-Nygaard \& Rasmussen 1970). The formation of the Middle Basalt Series initiated as explosive volcanism and accumulation of fragmental eruptive products. Following the explosive phase lava was apparently produced continously. After the formation of the Middle Basalt Series erosion took place before the Upper Basalt Serie was extruded. This series is only found on the northern islands and is approximately $0.7 \mathrm{~km}$ thick with a lavaflow thickness of $10 \mathrm{~m}$ on an average. The volcanism was of a rhytmic character with alternating layers of basalt and tuff. 


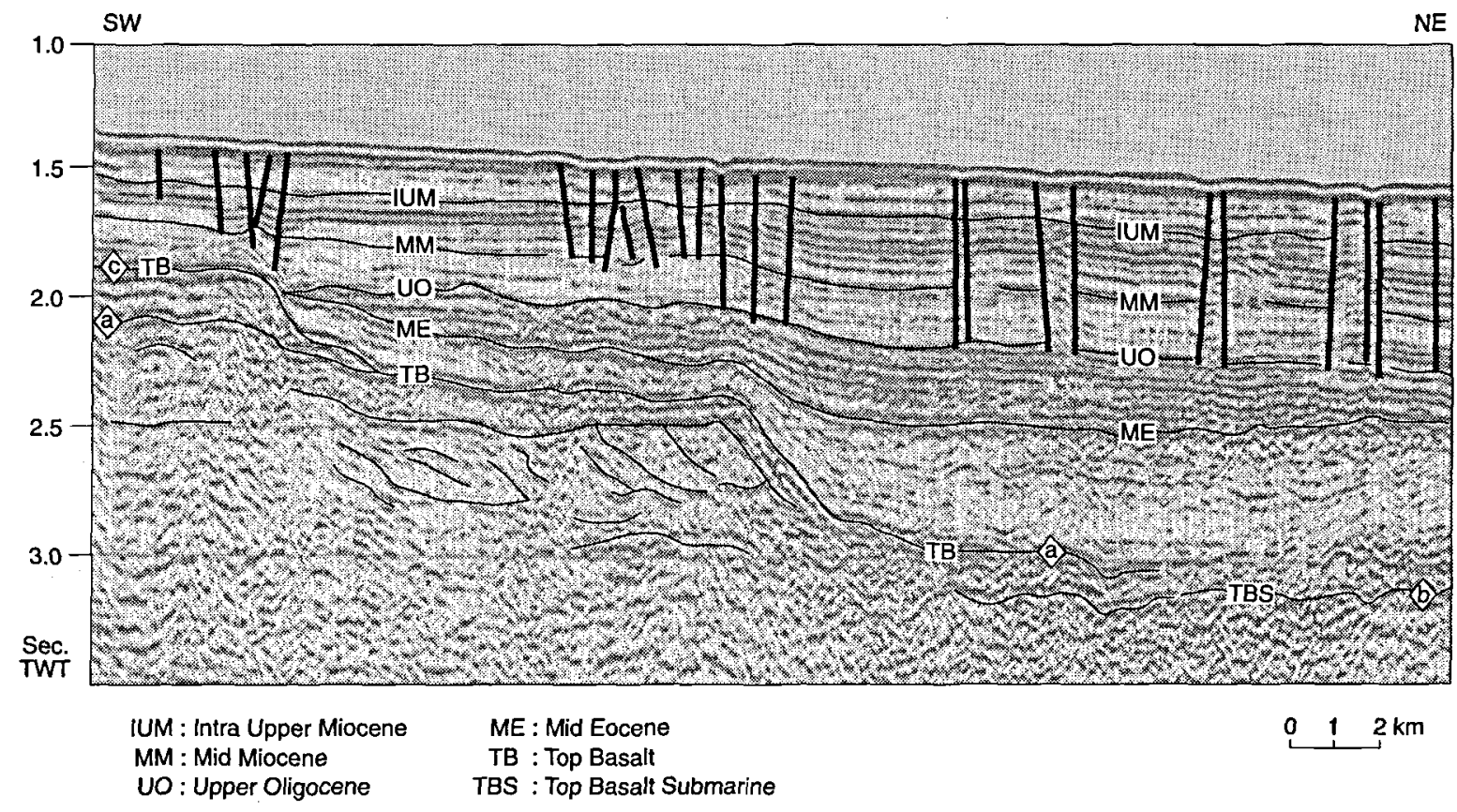

Fig. 5. Multi-channel reflection seismic profile showing a part of the Hatton-Rockall Escarpment. Note parallel bedded basalt facies, sigmoid basalt facies and hummocky basalt facies (TBS). Backstepping of primary volcanic escarpments are observed. Letters a-c represent isochron surfaces of the basalt. The faulting of the post Oligocene are interpreted as related to escape of water in the pelagic sediments, The continuation of this seismic profile is Fig. 8. Permission to publish from Geological Survey of Denmark and Orkustofnun, Iceland.

It has been suggested that the extrusive activity ceased in the Faeroe Islands before the opening of the NEAtlantic during C24R and that the Middle and Upper Series may be confined to a relatively narrow area along the continental margin (Waagstein 1988). This implies that the volcanic activity continued for 4-7 million years on the Faeroe Islands but that the major part of the volcanism occurred in the Thanetian (Waagstein 1988).

\section{Seismic images of the basalt}

The surface of the basalt constitutes a very pronounced reflector on single and multi-channel seismic reflection profiles. Despite the strong reflectivity of the surface of the basalt, it is observed that seismic energy can be transmitted through the surface and be reflected from within the basalt revealing internal reflector configurations. This allows seismic stratigraphy of volcanic rocks to be carried out as suggested by Gatliff, Hitchen, Ritchie, \& Smythe (1984). We have found that near vertical seismic energy is transmitted through the surface of the basalt and in places through the basalt allowing subbasalt reflections to be identified on the Faeroe-Rockall Plateau (Figs 2,4-8, Boldreel, Andersen, Kiørboe \& Laier 1993).

Based on reflector configuration within the basalts we identify seismic facies which relate to the environment into which the basalt was extruded (Wood, Hall \& Doody 1988, Boldreel et al. 1993).

On most of the Plateau the surface of the basalt is observed as a smooth, even and continuous reflector. Internal reflector configuration in the basalt succession (Fig. 4) indicate a rather continous and parallel internal bedding of the basalt. This is named the parallel bedded facies following the suggestions made by Wood et al. (1988). The parallel bedded facies is delimited towards the north and west by the occurrence of the Seaward dipping reflectors (Fig: 2). The parallel bedded basalt facies has been drilled both in the northern part of the Hatton-Rockall Basin in DSDP-well 117 (Laughton, Berggren et al. 1972) and further south in DSDP well 555 (Roberts, Schnitker et al. 1984) and it was found that the drilled basalt was subaerially extruded. In the northern part of the Faeroe-Rockall Plateau the parallel bedded facies is seen from the seismic profiles to outcrop at the seafloor around the Faeroe Islands. Thus it is concluded that the parallel bedded facies is related to subaerially extruded plateau basalts (Smythe 1983, Wood et al. 1988, Andersen 1988, Boldreel \& Andersen 1992).

In the central parts of the Rockall Trough and the Hatton-Rockall Basin the surface of the basalt is hummocky. The internal reflector pattern is chaotic and, at present, no coherent geological information is obtained below the basalt from seismic profiles (Figs $5 \& 8$ ). We 


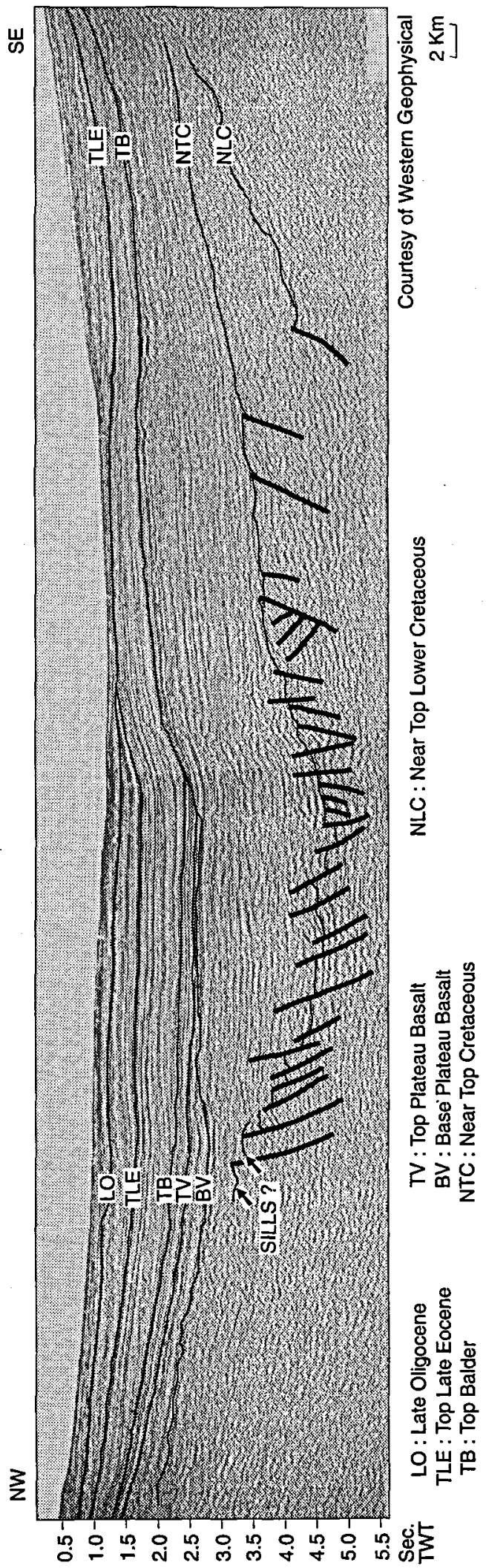

use the term volcanic hummocky basin floor facies for this reflector configuration.

The areas characterized by the hummocky basin floor facies in the Rockall Trough and the Hatton-Rockall Basin are horizontally bounded, except to the south, by regional primary volcanic escarpments (Fig. 2). At the primary volcanic escarpments seismic facies can be interpreted as connected to the lava entering the sea e.g. sigmoid/oblique (Wood et al. 1988). We find that the parallel bedded facies is found at the highest level behind the escarpment whereas, the hummocky facies type is found at the lower level in the basin in front of the escarpment (Figs 2,5). At the regional primary volcanic escarpments it is observed that the parallel bedded facies turns into oblique reflector patterns (Fig. 5). As suggested by Smythe (1983) this reflector pattern image the bed forms created when subaerial lava builds out into the sea or a lake as described from Iceland and West Greenland (Jones \& Nelson 1970, Heinesen 1987).

The seismic velocities of the volcanic seismic facies was studied by multi-channel reflection seismic and unreversed refraction seismic profiles in the Hatton-Rockall Basin in 1987 (Andersen, Boldreel, Gunnarson, Kjartansson, Ewing, Talwani \& Saywer 1990). The refraction seismic data were collected along the multi-channel reflection seismic profiles and this enabled direct integration of the two seismic methods. It was found that the parallel bedded facies was represented by seismic velocities in the interval $4.0-4.9 \mathrm{~km} / \mathrm{s}$ whereas the hummocky basin floor facies is characterized by the velocity interval of $3.0-3.8 \mathrm{~km} / \mathrm{s}$ (Fig. 2). Tertiary sediments on the Rockall Bank and in the southern part of the Hatton-Rockall Basin directly overlie acoustic basement (on the reflection seismic profiles) with refraction seismic velocities in the interval $5.0-5.9 \mathrm{~km} / \mathrm{s}$. On the southern and central part of the Rockall Bank rocks of Greenvillian and Laxfordian age have been sampled (Miller \& Mathews 1973, Roberts et al. 1973). Thus it is suggested that the velocity interval $(5.0-5.9 \mathrm{~km} / \mathrm{s})$ represents crystalline basement (Fig. 2).

The seismic velocities observed in the rocks represented by the hummocky basin floor facies is distinctly lower than the typical velocities $(4.5-5.5 \mathrm{~km} / \mathrm{s})$ in oceanic layer 2 (Christensen, Fountain \& Steward 1973) but comparable to the highest seismic velocities (3.4 $\mathrm{km} / \mathrm{s}$ ) in Quarternary (subglacial and shallow subacquatic) volcanic rocks on Iceland (Pàlmason 1971).

Based on the velocity information and the geographical distribution, seismic facies of the lower Tertiary volcanics relative to the regional primary volcanic escarpments we suggest that the hummocky basin floor facies

Fig. 6. Reprocessed multi-channel reflection seismic profile from the Faeroe-Shetland Channel. Note the suite of faultblocks from the UK area (SE) towards the Faeroe area (NW) and the gradual increase in thickness of the basalt. Permission to publish from Western Geophysical. 


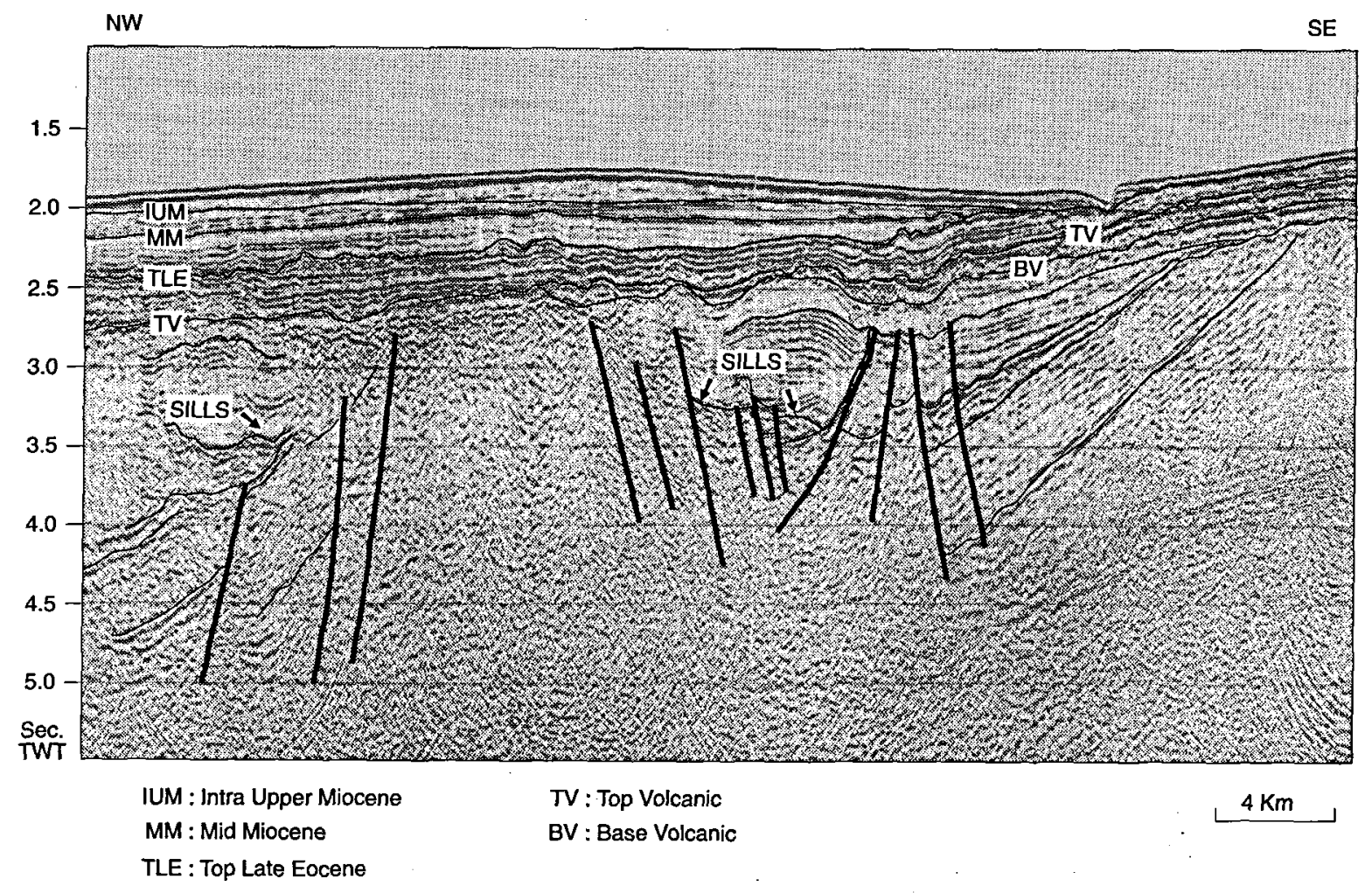

Fig. 7. Multi-channel reflection seismic profile from the southeastern part of the Hatton-Rockall Basin showing pre-basalt riftbasin. Permission to publish from Geological Survey of Denmark and Orkustofnun, Iceland.

represents lava extruded directly into the sea or possibly a lake. This would cause the basalt to become brecciated and probably highly vesicular. Breciation and irregular flow distribution of the basalt would cause the seismic energy to become scattered and cause the chaotic reflection pattern. Vesicles and possible interbedded sediments would contribute to the low velocity compared to the velocities of the volcanic parallel bedded facies and of oceanic basalt.

\section{Thickness of the Plateau basalt}

The thickness of the plateau basalt (Fig. 2) has been evaluated from results of a vertical seismic profile (VSP) carried out in the Lopra-1 well onshore the Faeroes in 1988 (Kiørboe \& Petersen 1992), newly acquired multichannel reflection deep seismic data in the Hatton-Rockall Basin (Andersen et al. 1990) and reprocessing of selected multi-channel reflection seismic data which were acquired in the northern part of the Faeroe-Rockall Plateau during the seventies (Boldreel et al. 1993).

The interpretation of the VSP data obtained in the Lopra-1 well show a pronounced strong negative reflec- tion at 0.92 TWT, which is approximately $200 \mathrm{~m}$ below the base of the well. This strong reflector is interpreted to be the base of the basalt which at this location rests on top of a low velocity layer (Kiørboe \& Petersen 1992). In the Hatton-Rockall Basin the thickness of the basalt is indicated where the base of the basalt have been identified on the reflection seismic profiles. The variation in the thickness of the basalt is from 0.1-1.1 s TWT which approximately equals $0.2-2.5 \mathrm{~km}$ using a seismic velocity of $4.5 \mathrm{~km} / \mathrm{s}$. The gradual increase in thickness of the basalt is illustrated by the results from a profile in the Faeroe-Shetland Channel (Fig. 6). On this profile it was found that the thickness of the basalt increases from $0.0 \mathrm{~s}$ TWT in the middle of the Channel to $0.4 \mathrm{~s}$ TWT $\sim 0.9$ $\mathrm{km}$ using the seismic velocity as above at a location 42 $\mathrm{km}$ further to the NW (Fig. 2). At this location the basalt has reached a thickness where the signal to noise ratio prevents the interpretation of the base of the basalt. Slightly to the NE of this profile part of another profile shows that the basalt is somewhat thicker $\sim 1.6 \mathrm{~km}$ before subbasalt information is lost. In the WyvilleThomson Ridge Complex area seismic profiles show a basalt thickness of $0.6-0.8 \mathrm{~s}$ TWT which roughly corresponds to a thickness of $1.3-1.8 \mathrm{~km}$ using a seismic velocity of $4.5 \mathrm{~km} / \mathrm{s}$ (Fig. 4). 


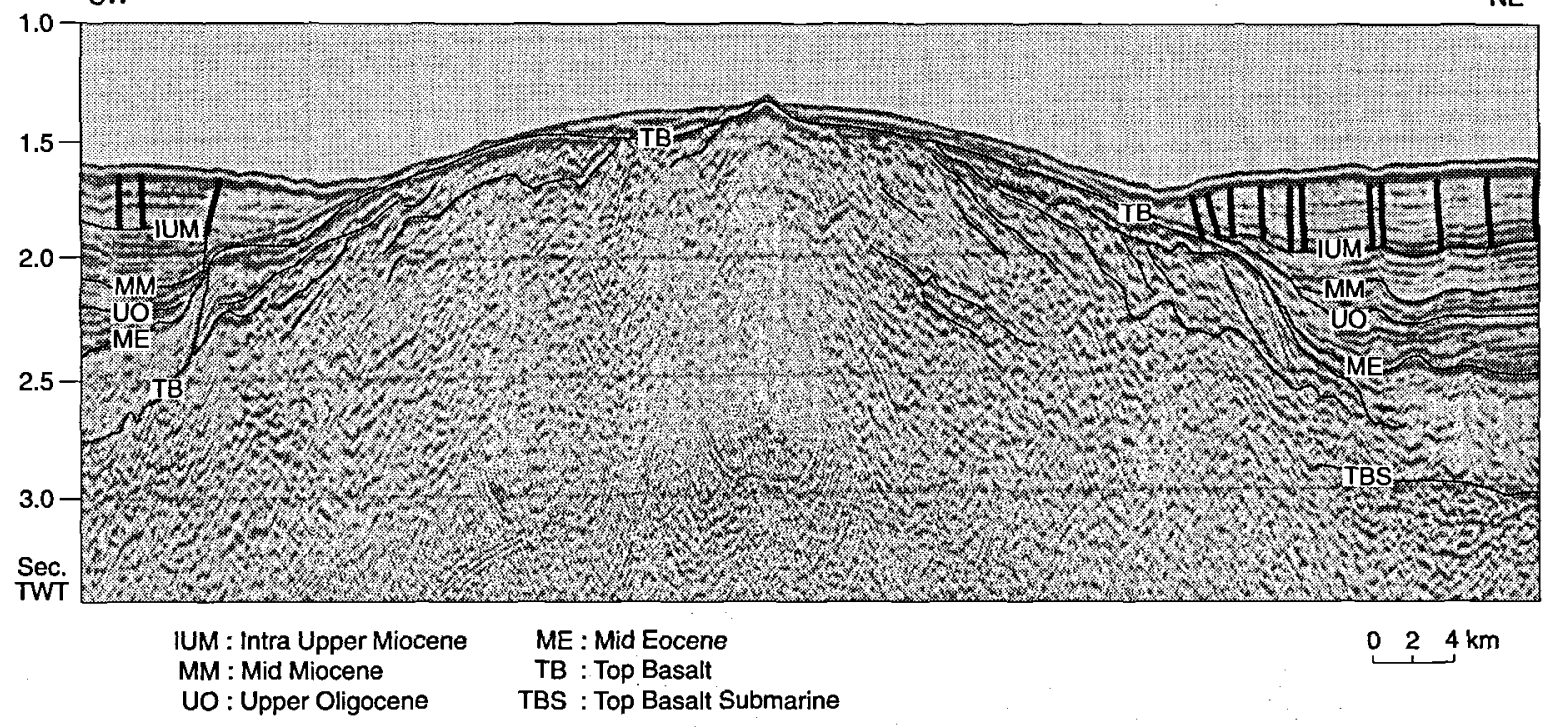

Fig. 8. Multi-channel reflection seismic profile showing the shield volcanoe named Mammal Seamount. Note the local primary volcanic escarpments on both sides of the volcanoe and the presence of submarine basalt (TBS) at the NE part of the profile. The faulting of the post Oligocene are interpreted as related to escape of water in the pelagic sediments. The continuation of this seismic profile is Fig. 5. Permission to publish from Geological Survey of Denmark and Orkustofnun, Iceland.

\section{The subbasalt geology}

Late Mesozoic rifting is well demonstrated in the eastern part of the Faeroe Shetland Channel (Hitchen \& Ritchie 1987, Mudge \& Rashid 1987). Rotated faultblocks related to this rift is observed from the middle of the Channel and about $40 \mathrm{~km}$ northwest below the plateau basalt (Fig. 6). A low velocity layer was suggested in the Faeroe Basin (Bott 1984) and it was interpreted to represent a substantial thickness of Mesozoic sediments. It was demonstrated by Hitchen \& Ritchie (1987) that considerable amounts of late Mesozoic sediments were located just outside the basalt covered area and from seismic profiles it is found that part of this sedimentary pile continues below the base of the basalt (Boldreel et al. 1993). This supports the suggestion made by Bott (1984).

On the Faeroe Islands traces of oil and gas have been isolated from the outflowing water of the Lopra-1 well. The biomarkers of the oil as well as the stable isotopes of metane, ethane and propane may suggest that these hydrocarbons derive from a thermally mature source rock, consisting of marine sediments, located below the basalt (Laier \& Nytoft, 1993a,b). In the Wyville Thomson Ridge Complex area the plateau basalt lap onto an erosional surface. Two seismic units affected by pre-volcanic faulting are observed below the plateau basalt (Fig. 4). In the Hatton-Rockall area riftbasins are identified below the basalt cover (Fig. 7, Andersen et al. 1990, Neish 1993). Apparently a thin postrift unit excists between the basalt and rift sediments.

\section{Subsidence}

During the Tertiary the Faeroe-Rockall Plateau has subsided considerably. Presumably these isostatic movements are caused by the cooling of the asthenosphere and lithosphere following the volcanism in the early Tertiary (Smythe 1983; Roberts et al. 1984a; White et al. 1987; Andersen 1988). The amount of total post-volcanic subsidence (TPVS) on the plateau varies. But ideally, the subsidence can be estimated from the present depth of the breakpoints of the regional primary volcanic escarpments as the location of the breakpoint represent the paleocoastline at the time of extrusion (Jones 1966). In the Rockall Trough and in the Hatton-Rockall Basin part of the escarpments are composed of up to three well defined backstepping escarpments (Figs $5 \& 9$ ). Knowing that on the Faeroe Islands the volcanic activity lasted for 4-7 mill. years, with intermittent breaks in activity (Waagstein 1988), it is possible that these succesive breaks are indicative of changes in the relative sealevel due to regional subsidence. Eruption of magma produced local subsidence due to withdrawal of magmas from subsurface reservoirs. However, unless eruption-induced subsidence (EIS) is restricted it will not be of the same magnitude as the height of the lavapile. We see no indications of local synforms along the escarpment and do thus conclude that EIS mostly is confined to areas which now are covered by plateau basalts and that basins generated by EIS are camuflaged below and within the basalt cover. The area which most likely underwent EIS is the 

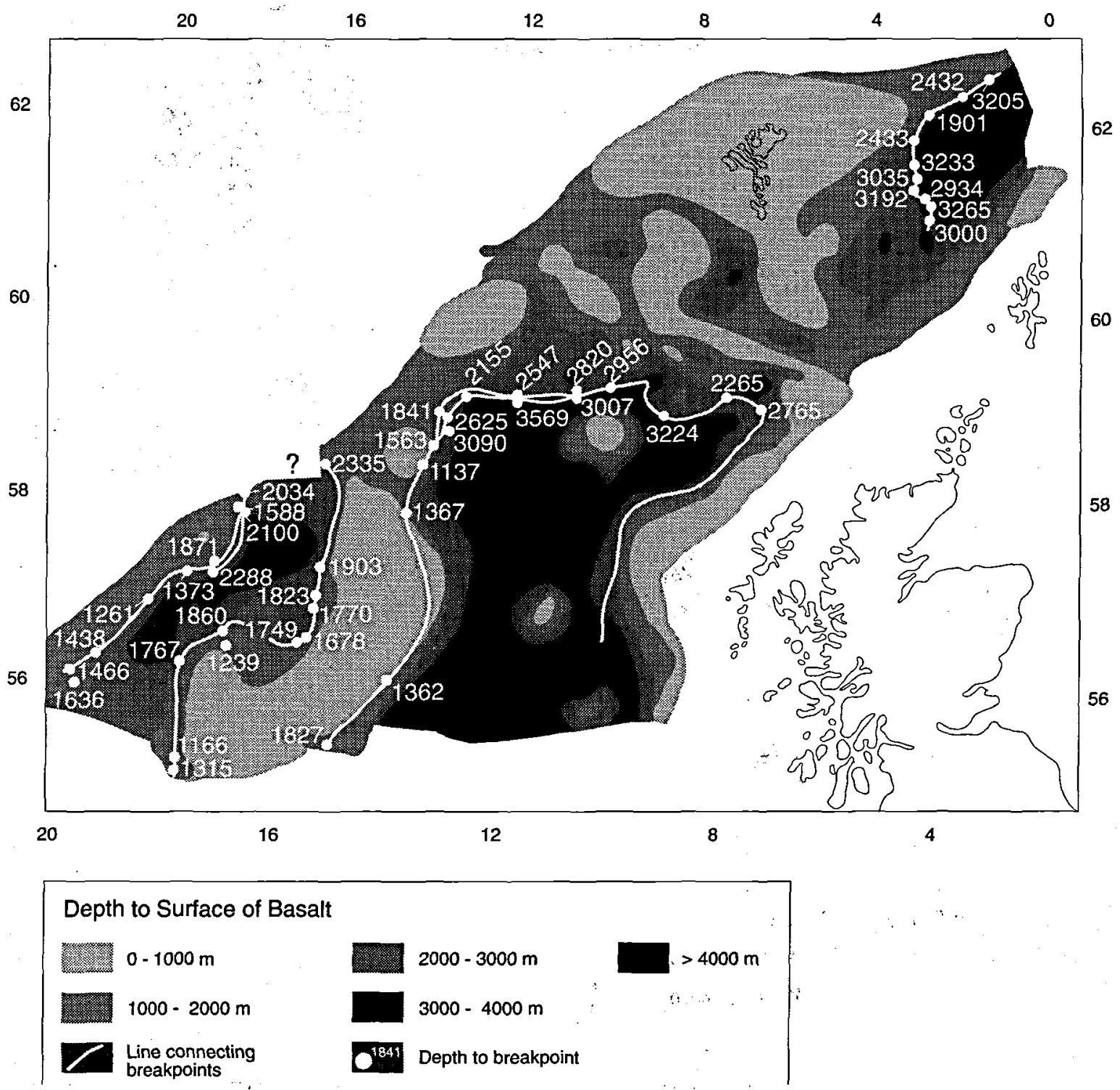

Fig. 9. Subsidence map showing the depth to the breakpoints at the regional primary volcanic escarpment. In the Rockall Trough and in the Hatton-Rockall Basin it can be seen that part of the Rockall Trough Escarpment and the Hatton-Rockall Basin Escarpment consist of more than one well-defined level of breakpoints. The line connecting the depths values of the breakpoints is for illustration and need not connect breakpoints at identical stratigraphic levels. The background of the figure is the depth map to the stratigraphic level of the top of the basalt.

area of the SDR on the northern and western continental margin (Smythe 1983, Palmason 1965).

We do thus conclude that the backstepping primary volcanic escarpments is indicative of mostly syn-volcanic tectonic or thermal subsidence in the order of several hundred meters in not more than 4-7 mill. years.

The overall impression is that the Rockall Trough and the Faeroe-Shetland Channel has been subject to total post volcanic subsidence of up to $3500 \mathrm{~m}$ while the Hatton-Rockall Basin has subsided by less than $2300 \mathrm{~m}$. In the Rockall Trough and the Hatton-Rockall Basin the depth to the breakpoints is largest in the northern parts. We see no indications that basalt is missing caused by erosion in the southern parts of the basins. Therefore the northern parts of the basins may have undergone larger TPVS than the southern parts. In the Faeroe-Shetland Channel the depth to the breakpoint of the Faeroe-Shetland Escarpment is undulating between $1901 \mathrm{~m}$ and 3265 $m$ within a fairly small area (Fig. 9). Where the FaeroeShetland Escarpment aligns two compressional ridges, the Fugloy Ridge and the East Faeroe High, the escarpment has been exposed to tectonic compressional uplift 


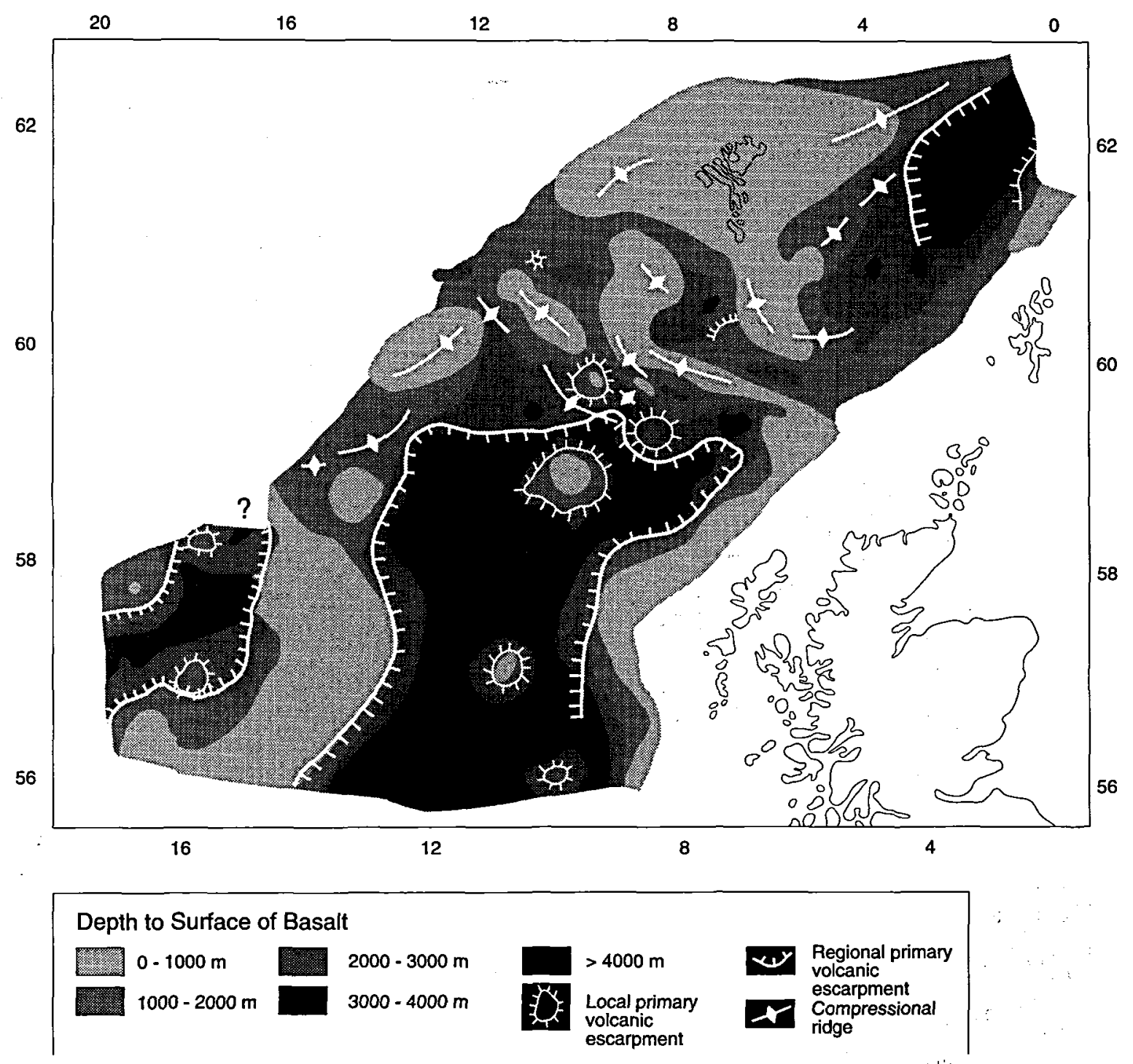

Fig. 10. Depth map to the stratigraphic level of the surface of the basalt. Regional and local primary volcanic escarpments and compressional ridges are marked on the map illustrating the different geological structures forming the topography of the basalt.

which accounts for the locally shallower levels of the breakpoint line at these locations (Figs 2 and 10, Boldreel \& Andersen 1992).

Minimum TPVS values can also be obtained from the depth to the surface of the subaerial extruded plateau basalt on the landward side of the escarpments (Fig. 10). Assuming that the primary slope of the plateau basalt is known and no erosion has taken place actual TPVS values can be estimated. From the seismic interpretation it is possible to outline areas where the influence of compression seems not to be present. At these locations the depth to the surface of the Plateau basalt is around 1000-2000 $\mathrm{m}$ which is suggested to be the minimum general TPVS of the plateau.

\section{Primary morphology of the volcanic rocks on the Faeroe-Rockall Plateau}

The volcanic activity on the Faeroe Islands came to a halt, approximately at the same time that seafloor-spreading was initiated in the NE Atlantic Ocean at the boundary between the Paleocene and Eocene. At this time the breakpoints of the three major regional primary volcanic escarpments presumably still were close to sea-level, but subsiding fairly rapidly as indicated by the backstepping of the escarpments (Figs 5 \& 9). The topographic maximum of the plateau was somewhere between the escarpments and the line of break-up, presumably very close to 


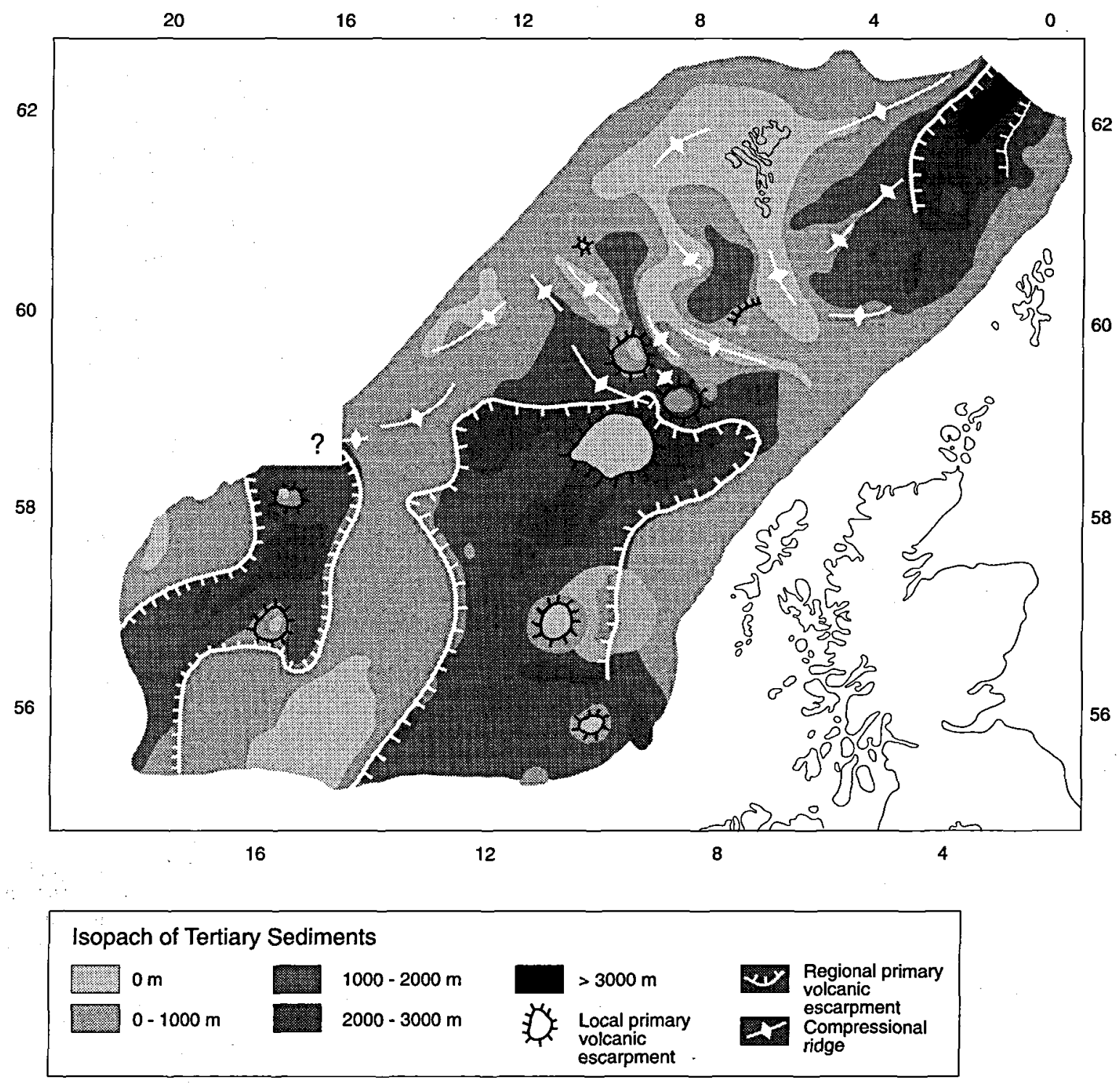

Fig. 11. Isopach map of the Tertiary sediments found above the stratigraphic level representing the surface of the basalt. The location of structurel elements: regional primary volcanic escarpments, local primary volcanic escarpments and compressional structures (consult Fig.2 for legend). The location of the regional primary volcanic escarpments outline three basinal areas. The local primary volcanic escarpments and compressional structures show areas with thin sedimentary cover. The compressional induced basins show up as local depocenters.

the latter as indicated by westward transport of Paleogene sediments. This paleo-topography is reflected in the isopach of Lower Tertiary to Recent sediments (Fig. 11).

During the Eocene and Oligocene sediments were deposited in the basins outlined by the regional escarpments. The overall geometry of the Eocene-Oligocene succession, and the reflector configuration within the succession indicate that sediments were supplied from beyond the margin of the basins. The Faeroe-Shetland Channel is primarily supplied with sediments from the
East (i.e. the West Shetland Platform), while the HattonRockall Basin was supplied from the west, as the heavy mineral assemblages in DSDP wells 403, 404, 553 and 555 also indicate (Morton 1984). In the Rockall Trough there is seismic indication of sediment supply both from east and west or northwest.

The sediment isopach map (Fig. 11) and the map of the depth to the surface of the basalt (Fig. 10) also clearly indicate the occurence of a number of steep sided and flat topped seamounts. They have been confirmed as mag- 
matic centres from gravimetric and magnetic data (Boldreel 1994). Some of these seamounts may be of a similar age as the plateau basalts, as the depth to breakpoint of the local escarpment around these seamounts correlates closely with the height of the regional escarpments (e.g. Mammal Seamount in the Hatton-Rockall Basin Figs 5 \& 8). However, the breakpoints of the local escarpments around most of the seamounts are located at a considerably higher level than the regional escarpments, and several of the seamounts are actually located on top of parallel bedded basalt. Most of the central volcanic activity in this area did therefore occur after the flood basalt were subsided below sealevel(i.e. being of Eocene or younger age). A few of the volcanic centers might, however, be older. Maastrichtian nanofossils have been dated from Rosemary Bank and Anthon Dohrn Seamount (Jones, Ramsay, Preston \& Smith 1974) and Ar-Ar dates do to some extent support a Maastrichtian age of the Rosemary Bank. The breakpoint of the highest situated volcanic escarpment on Rosemary Bank is approximately $2000 \mathrm{~m}$ higher than the breakpoint of the nearby Rockall Trough Escarpment, this implies $2000 \mathrm{~m}$ Maastrichtian to Paleocene uplift in the Rockall Trough.

\section{Compressional structures}

As mentioned above a number of compressional structures on the northern and western part of the FaeroeRockall Plateau have been identified from multi-channel seismic profiles (Figs 4, 10 \& 12, legend found on Fig. 2, Boldreel \& Andersen 1992, 1993). These structures are identified by the folding of parallel bedded basalts (Figs 4 \& 12).

Around the three WNW-ESE trending anticlines Wyville-Thomson Ridge, Ymir Ridge, and Bill Bailey Bank it is seen that the same sequence display onlap on one side of the structure and is uplifted and truncated on the other side (Fig. 12). Based on this assymetry it is inferred that these compressional ridges are ramp anticlines located above fault planes (Boldreel \& Andersen 1993) and the location of the structures may be caused by reactivation of older fault systems.

The compressional structures on the northern part of the Faeroe-Rockall Plateau, to the north of the Lousy Bank (Fig. 10) have been subjected to compression over a fairly long period from late Paleocene or early Eocene to the Miocene. This is concluded as the internal reflector configuration in the post basaltic sedimentary section exhibit a number of onlap/uplift related to tectonic processes. The structures along the western part of the Plateau south of the Bill Bailey Bank (Fig. 10) seem to have been subjected to one compressional phase corresponding to the latest phase of the compression further north (Boldreel \& Andersen 1993).

It is suggested that deformation of the Wyville-Thomson Ridge, Ymir Ridge, and Bill Bailey Bank in the Eocene was caused mostly by N-S compressional stress due to ridge-push (Boldreel \& Andersen 1993). A more detailed analysis of the deformation pattern along these ridges indicates that nearly NE-SW compressional stress is more likely. Later deformation appears to be associated with NW-SE compression. Geofroy, Angelier \& Bergerat (1993) studied joints and faulting on the Faeroe Islands and identified post-volcanic compression with the maximum compressional stress oriented ENE.

\section{Contour currents}

Since Miocene times, cold dense water has formed the bottom waters in the Norwegian Basin. On its way to the south the bottom water passes the Greenland-IcelandFaeroe-Scotland Ridge and it is estimated that at present $30 \%$ of the flow of cold bottom water takes place through the Faeroes Channels (Faeroe-Shetland Channel and the Faeroe Bank Channel; Fig. 1, Meincke 1983). The top of the ridge is rather shallow typically less than $500 \mathrm{~m}$ whereas the threshold level in the Faeroe channels on the very eastern end of the ridge is approximately $800 \mathrm{~m}$ deep (Fig. 1). This causes the bottom waters either to be dammed against the ridge until overflow commences or to flow SE along the ridge, as shown by Bowles and Jahn (1983), and into the narrow Faeroe Channels (Fig. 1). The present shape of the Faeroe Channels results from a complex interaction of primary topography of the surface of the plateau basalt, compression and thermal susbsidence as outlined from the structural and pre-Upper Pliocene map by Boldreel \& Andersen (1992) (Fig. 13). At the time volcanic activity ceased, the Faeroe-Shetland Channel and the Rockall Trough were already below sealevel, and subsiding rapidly. The Wyville-Thomson Ridge was elevated (as were the Ymir Ridge, the Bill Bailey Bank, the Munkegrunnar Ridge, the Faeroe Bank, the East Faeroe High and the Fugloy Ridge) during the early Eocene to Miocene compression events which also formed the Faeroe Bank Channel as a syncline between compressional structures (Fig. 10). Thus the WyvilleThomson Ridge became a barrier to the main part of the south flowing bottom waters, which was guided from the Faeroe-Shetland Channel into the Faeroe Bank Channel. It has been suggested that the bottom water flowed directly from the Faeroe-Shetland Channel into the Rockall Trough during most of the Neogene (Ellet \& Roberts

Fig. 12. Multi-channel reflection seismic profile showing a compressional ridge: the Bill Bailey Bank. At the top of the compressional ridge the basalt is erosional truncated where it is exposed at the sea-floor. Note the uplift and erosion of older sediments on the SW flank of the ridge and the onlap at the NE flank. Profile recorded by the Geological Survey of Denmark and University of Aarhus, Denmark. Permission to publish by the Geological Survey of Denmark. 

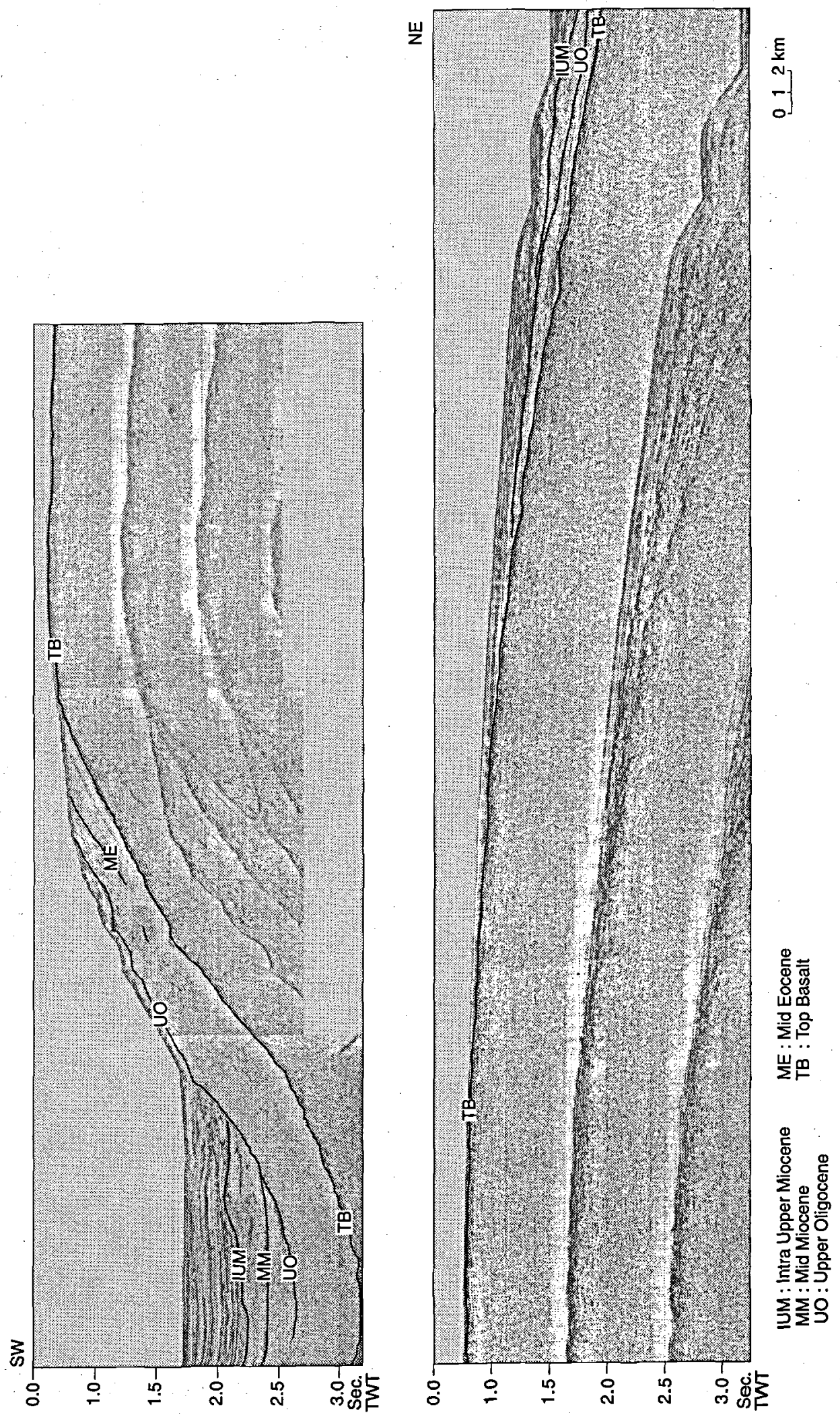

Boldreel \& Andersen: Tertiary development 
1973) and it has long been known that the WyvilleThomson Ridge only developed as a barier to the south moving water in the late Miocene (Roberts 1975; Miller \& Tuckolke 1983; Richards, Ritchie, \& Thomson 1987) which is in accordance with the timing of the development of the Wyville-Thomson Ridge (Boldreel \& Andersen (1993).

The seabed in the central part of the Faeroe-Shetland Channel is rather flat and the width of this flat bottom of the channel narrows towards the south at the same time as the seabed raises in a southerly direction approaching the Munkagrunnar Ridge (Fig. 13). Successively older sedimentary sequences outcrop in the central part of the Faeroe-Shetland Channel in southern direction indicating that erosion and non-deposition increase toward the southern part of the Channel. It is suggested that this is caused by bottom water being funneled into the FaeroeShetland Channel resulting in an increasing velocity (Fig. 13, Boldreel \& Andersen 1992). Where the bottom water meet the Wyville-Thomson Ridge the main part is forced along this structure to the west into the Faeroe Bank Channel. The Faeroe Bank Channel is a rather wide basin which beeing a sedimentary sink where up $2100 \mathrm{~m}$ of sediments has accumulated during the Tertiary (Fig. 11). However, the main flow of bottom water appears to be confined within a rather narrow area where older sequences are exposed on the sea-bed (Fig. 13). At the outlet of the Faeroe Bank Channel the width of the syncline narrows and the basalt outcrops at the seafloor indicating erosion or non-deposition at this locality (Boldreel \& Andersen 1992). Further westwards fairly thick Neogene deposits are found. A part of the overflowing water may have been guided by the topography into the syncline between the Wyville-Thomson Ridge and the Ymir Ridge. From here on it passes through a marked submarine valley which is a result of the reverse faulting in connection to the compressional regime (Fig. 13). As a consequence, the water would thus pass the western part of the Ymir Ridge. But Sigmundur Seamount acted as a barrier for flow further south and until the seamount was buried in sediments, bottom water would flow north between the Faeroe Bank and the Bill Bailey Bank (Andersen \& Boldreel 1992). In this area several erosional unconformities within the Neogene are seen on the seismic profiles (Andersen \& Boldreel 1992). This has been interpreted as the result of significant fluctuation in the rate of the deep water flow through the Faeroe Channels i.e. during periods of high flow the bottom water was dammed in the southern part of the Faeroe-Shetland Channel thus allowing the increased flow of bottom waters over the Wyville-Thomson Ridge (Andersen \& Boldreel 1992).

\section{Conclusion}

The Faeroe-Rockall Plateau is covered by Paleocene basalts which mainly consist of subaerially extruded plateau basalt and to a lesser degree of basalt extruded in a aquatic environment (Fig. 2). By means of interpretation of reflector configuration and seismic velocities within the basalts, it is possible to differentiate between the two groups of basalt. Outside the basaltcovered area the Balder tuff horizon is almost time equivalent to the surface of the basalt.

Recent seismic reflection data and recently reprocessed older seismic profiles images geological structures below the subaerially extruded basalt cover. Pre-volcanic rift basins of unknown age are recognized on the basis of tilted faultblocks and distinct seismic sequences.

Eocene and younger sediments in the Faeroe-Rockall Plateau area are deposited on the surface of the basalt. The distribution of these sediments is on a regional scale the result of the interaction between four different factors.

1) Three major basins (the Rockall Trough, the FaeroeShetland Channel and the Hatton-Rockall Basin) were established as a result of the volcanic activity as indicated by the presence of regional primary volcanic escarpments. During the Paleogene these basins were the major depositional areas (Fig. 11).

2) The Faeroe-Rockall Plateau area has been subject to post-volcanic subsidence as seen from the submerged breakpoints at the primary volcanic escarpments. The amount of total post-volcanic subsidence can be established from the depth to the breakpoints of the regional escarpments. The largest amount of total post-volcanic subsidence, approximately $3 \mathrm{~km}$, is seen in the northern part of the Rockall Trough and in the Faeroe-Shetland Channel (Fig. 9). A number of younger volcanoes rise from the surface of the plateau basalt (Fig. 10). Knowing the age of the volcanoes, the breakpoint of the escarpments around these, has the potential to establish further points on the subsidence curve in this area (e.g. $2000 \mathrm{~m}$ of Maastrichtian-Paleocene uplift is indicated by the level of the highest breakpoint on Rosemary Bank).

3) Compressional tectonics have influenced the Faeroe-Rockall Plateau during the Tertiary and a number of compressional ridges (Figs $4 \& 12$ ) and some compressional induced basins have been formed which affected the distribution of the tertiary sediments in the area (Fig. 11).

4) In the Neogene, deep water currents of Norwegian Sea Deep Water played a role in the distribution of the sediments. These currents were guided by the existing topography caused by regional subsidence and compressional tectonics (Fig. 13). Erosion took place in the Faeroe-Shetland Channel and deposition occurred in the Faeroe Bank Channel and in the small basin between the Bill Bailey Bank and the Ymir Ridge (Fig. 11).

\section{Acknowledgements}

Western Geophysics as well as Orkustofnun (Iceland) and Geological Survey of Denmark are thanked for the permission to publish seismic sections. This paper benefitted 


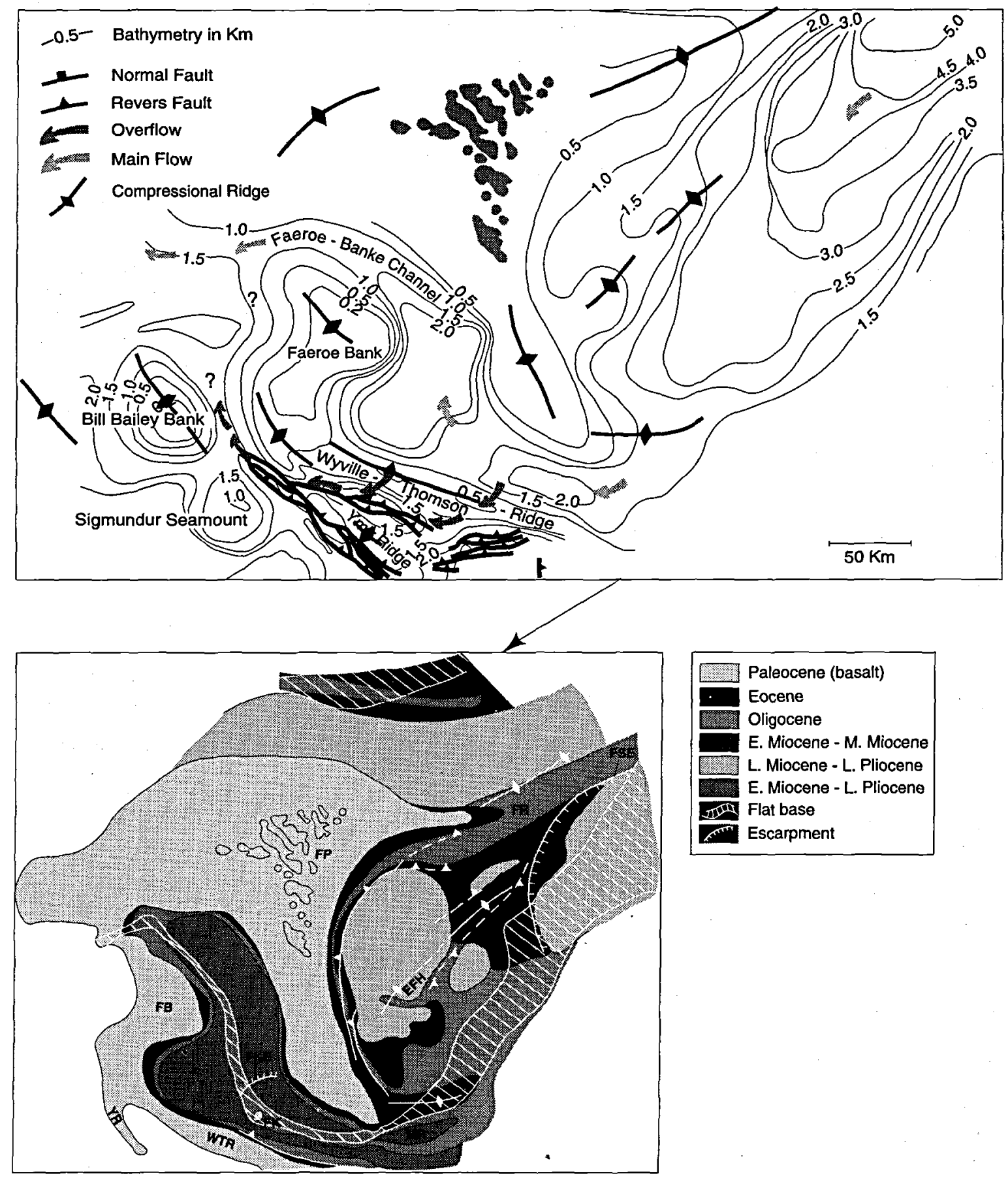

Fig. 13. Top: Bathymetric map with structural elements (compressional ridges and reverse faults) as expressed by the surface of the basalt. The directions of the mainflow and overflow of the deep water currents are shown. Bottom: Pre upper Pliocene outcrop map of part of the Norwegian Basin, the Faeroe-Shetland Channel and the Faeroe Bank Channel. The pre upper Pliocene is rather thin/absent in this area. It is seen that the flat base narrows towards the south in the Faeroe-Shetland Channel and succesively older sequences outcrop. In the Faeroe Bank Channel the flat base becomes narrow and erosion/non-deposition is seen here as in the Faeroe-Shetland Channel. Selected structural elements and the flat base of the Faeroe-Shetland Channel are shown. FSE: Faeroe-Shetland Escarpment, FR: Fugloy Ridge, FP: Faeroe Platform, EFH: East Faeroe High, FK: Faeroe Knoll, FKE: Faeroe Knoll Escarpment, FB: Faeroe Bank, WTR: Wyville-Thomson Ridge, YR: Ymir Ridge. 
from valuable discussions with collegues at the Faeroes Section, DGU.

\section{Dansk sammendrag}

Færø-Rockall Plateauet er beliggende i NØ-atlanten mellem Island og Skotland (Fig. 1). Plateauet er karakteriseret af tilstedeværelsen af et sen Paleocænt-Eocænt basaltdække (Fig. 2), der blev dannet i forbindelse med åbningen af $\mathrm{N} \emptyset$-atlanten, som resulterede $\mathrm{i}$ adskillelsen af Europa og N.Amerika. Mod nord og vest (Norske Bassin og Islandske Bassin, Figs 1-2) findes oceanisk skorpe og overgangen til Plateauet markeres af de såkaldte "seaward dipping reflectors sequence". Indsamlede prøver af Prækambrisk grundfjeld, unders $\emptyset$ gelser af plateaubasaltens geokemi samt spredte geofysiske undersøgelser af skorpens beskaffenhed viser at Plateauet er underlagt af kontinental skorpe. Plateauet er adskilt fra den NV-europæiske kontinental sokkel af to dybe bassiner med tynd skorpetykkelse (Rockall Truget og FærøShetland Kanalen, Fig.1). Det er endnu ikke endelig klarlagt om disse bassiner er underlagt af oceanisk eller kontinental skorpe eller hvornår de blev dannet.

Overfladen af basalten er en meget kraftig reflektor. Derfor er det sjældent muligt at bedømme tykkelsen af basalten samt, hvad der findes under dækket. Kun i begrænsede områder f.eks. Færø-Shetland Kanalen, HattonRockall Bassinet, Wyville-Thomson Ryg Komplekset (Figs 4, 6-7) og i Færø-Shetland Kanalen har det været muligt ud fra seismiske profiler at se blokforkastninger og riftbassiner under basalten, samt bedømme tykkelsen af basalten (Fig.2). På Færøerne består basalten af tre serier (Fig.3). I 1980-81 blev der boret 2 dybe boringer (Vestmanna-1 og Lopra-1) i basalten. I 1988 blev der indsamlet nye seismiske data (vertikal seismisk profilering) $\mathrm{i}$ den $2178 \mathrm{~m}$ dybe Lopra-1 boring. Tolkningen af data viser en markant grænse, som sandsynligvis repræsenterer underlaget af basalten, ca. $250 \mathrm{~m}$ under brønden. Gas og vandprøver udtaget i Lopra-1 boringen i 1983 og 1992 viser tydelige oliespor og biomarker analyser viser, at olien sandsynligvis stammer fra en sedimentær moderbjergart, der må ligge under basalten.

Basalt overfladen er dækket af varierende mægtigheder af tertiære sedimenter (Fig.11). Fordelingen af sedimenterne er bestemt af den topografi, der blev etableret under den vulkanske fase, den temiske indsynkning og fordelingen af kompressionsstrukturer. I Neogen har strømme af koldt bundvand også haft betydning for fordelingen af sedimenterne.

På grundlag af tolkning af seismiske refleksions- og refraktionsdata inddeler vi basalten $i$ to hovedtyper. Den mest vidtspredte er plateaubasalt, som kan sammenlignes med basalten på Færøerne. Den er dannet ved udbrud over havniveau, mens den anden type er dannet $i$ forbindelse med akvatisk miljø (Fig.2). Overgangen mellem de to typer er markeret af 3 regionale stejlskråninger (escarpments) af primær vulkansk oprindelse (Fig.5). Stejl- skråningerne viser beliggenheden af palæokystlinien på udbrudstidspunktet og højden af stejlskråningerne giver et indtryk af bassindybden. Stejlskråningerne markerer således, at der oprindelig har eksisteret et dyberebeliggende område bestående af Hatton-Rockall Bassinet, Rockall Truget samt den nordlige del af Færø-Shetland kanalen (Figs 1, 10). Denne oprindelige overordnede topografi er lokalt modificeret ved et antal vulkanske centre.

I løbet af tertiær har området været udsat for en betydelig indsynkning. Indsynkningen, som bl.a. skyldes afk $\emptyset$ ling af asthenosfæren og lithosfæren efter den tidlige tertiære vulkanisme, kan bestemmes langs de vulkanske stejlskråninger, og har været størst i Rockall Truget og Færø-Shetland Kanalen, hvor den er $2-3 \mathrm{~km}$., mens den er 1-2 km. på Færø-Rockall Plateauet (Fig.9).

På den nordlige samt den vestlige del af Plateauet findes et antal kompressionsstrukturer (Figs 10-12) bl.a. Wyville-Thomson Ryg Komplekset (Fig.4) som kan identificeres på seismiske profiler. Der har været flere kompressions faser. Det observerede deformationsmønster foreslår at strukturerne er dannet ved rygskub (ridgepush) udviklet $i$ forbindelse med dannelsen og nedsynkningen af oceanisk skorpe i $N \varnothing$-atlanten.

Den termale indsynkning af Færø-Shetland Kanalen og Rockall Truget har forårsaget, at koldt bundvand fra nord i løbet af Tertiær fik mulighed for at strømme sydpå øst om Færøerne gennem Færø-Shetland Kanalen. Indtil Miocæn synes dybhavsstrømmene fortrinsvis at have bevæget sig gennem Færø-Shetland Kanalen hen over Wyville-Thomson Ryg Komplekset og videre til Rockall Truget (Fig.1). I Miocæn blev Wyville-Thomson Ryg Komplekset en markant forhindring for disse bundstrømme, hvorefter de hovedsagelig bevægede sig gennem Færø Banke Kanalen og videre ud i Atlanterhavet (Fig.13). Dannelsen af kompressive strukturer og den termale indsynkning af Plateauet spiller en vigtig rolle $i$ fordelingen af de post-Tertiære sedimenter og kontrollerer i udstrakt grad forløbet af dybhavsstrømmene omkring Færøerne (Fig.13).

\section{References}

Andersen, M. S. 1988: Late Cretaceous and early Tertiary extension and subsidence around the Faeroe Islands. In Parson, L. M. \& Morton, A. C. (eds) Early Tertiary Volcanism and the opening of the NE Atlantic, Geological Society Special Publication no. $39,115-122$.

Andersen, M. S. \& Boldreel, L. O. 1992: Effect of EoceneMiocene Compression Structures on Bottom Water Currents in the Faeroe-Rockall Area. Paper presented at "the Tectonics, Sedimentation and Paleoceanography og the North Atlantic Region" Geological Society of London, Edinburgh Meeting 28-29/9, 1992. Abstractbook p. 2. Submitted for publication special publication of the Geological Society.

Andersen, M. S., Boldreel, L. O., Gunnarson, K., Kjartansson, E., Ewing, J., Talwani, M. \& Saywer, D. 1990: A seismic investigation of the Rockall Plateau. Annales Geophysicae, Special Issue, 63.

Bertelsen O., Noe-Nygaard, A. \& Rasmussen J. (eds) 1984: The 
deep drilling project 1980-1981 in the Faeroe Islands. Føroya Frodskaparfelag, Torshavn, $159 \mathrm{pp}$.

Boldreel, L. O. 1994: Volcanoes and compressional structures on the Faeroe-Rockall Plateau (NE-Atlantic) studied from multichannel reflection seismic and gravity. 21. Nordic Geological Wintermeeting Luleå. Abract p.31

Boldreel, L. O. \& Andersen, M. S. 1992: The Relationship between the Distribution of Tertiary Sediments and Tectonic Processes and Deep Water Circulation around the Faeroe Islands. Paper presented at "the Tectonics, Sedimentation and Paleoceanography og the North Atlantic Region" Geological Society of London, Edinburgh Meeting 28-29/9, 1992. Abstractbook p. 5. Submitted for publication special publication of the Geological Society.

Boldreel, L. O. \& Andersen, M. S. 1993: Late Paleocene to Miocene Compression in the Faeroe-Rockall Area. In Parker, J. R. (ed.) Petroleum Geology of Northwest Europe: Proceedings of the 4th Conference, 1025-1034.

Boldreel, L. O., Andersen, M. S., Kiørboe, L. \& Laier, T. 1993: Indications of the thickness of the Plateau basalt and subbasalt geology in the Faeroe-Rockall Area. Extended abstract EAPG 1993 Paper E038.

Bott, M. H. P. 1984: Deep structure and origin of the FaeroeShetland Channel. In Spencer, A. M., Holter, E., Johnsen, S. O., Mørk, A., Nysæther, E., Songstad, P. \& Spinnangr, A. (eds) Petroleum Geology of North European Margin, 341349.

Bott, M. H. P., Nielsen, P. H. \& Sunderland, J. 1976: Converted P-waves Originating at the Continental Margin between the Iceland-Faeroe Ridge and the Faseroe Block. Royal Astronomical Society, geophysical Journal 44, 229-238.

Bowles, F. A. \& Jahn, W. H. 1983: Geological/Geophysical Observations and Inferred Bottom-Current Flow: South Flank Iceland-Faeroe Ridge. Marine Geology 52, 159-185.Nordic seas

Christensen, N. I., Faurtain, D. M. \& Stewart, R. J. 1973: Oceanic crustal basement: a comparison of seismic properties of D.S.D.P. basalts and consolidated sediments. Marine Geology $15,215-226$.

Eldholm, O., Thiede, J., Taylor, E. et al. 1989. Proceedings of the Ocean Drilling Program Scientific Results volume 104, $1-1141$.

Ellet, D. J. \& Roberts, D. G. 1973: The overflow of Norwegian Sea Deep Water across the Wyville-Thomson Ridge. DeepSea Research 20, 819-835.

Gariepy, C., Ludden , J. \& Brooks, C. 1983: Isotopic and trace element constraints on the genesis of the Faeroe lava pile. Earth and Planetary Science letters 63, 257-272.

Gatliff, R. W., Hitchen, K., Ritchie, J. D. \& Smythe, D. K. 1984: Internal structure of the Erlend Tertiary volcanic complex, north of Shetland, revealed by seismic reflection. Journal of the Geological Society 141, 555-562.

Geofroy, L., Angelier, J. \& Bergerat, F. 1993: Sur l'evolution tectonique cassante tertiaire des Iles Feroe, Atlantique Nord; la compression feringienne. C.R. Academic Science Paris, t. 316, serie II, 975-982 (Abridged english version).

Hald, N. \& Waagstein, R. 1983: Silicic basalts from the Faeroe Islands: Evidence of crustal contamination. In Bott, M. H. P., Saxov, S., Talwani, M. \& Thiede, J. (eds) Structure and development of the Greenland-Scotland Ridge NATO Conference series, Serie IV: Marine Science, 343-349. Plenum Press, New York/London.

Hald, N. \& Waagstein, R. 1984: Lithology and geochemistry of a 2-km sequence of Lower Tertiary tholeiitic lavas drilled on Suduroy, Faeroe Islands (Lopra-1). In Berthelsen, O., NoeNygaard, A. \& Rasmussen, J. (eds) The deep drilling project 1980-1981 in the Faeroe Islands, 13-38. Føroya Frodskarfelag.

Hanisch, J. 1984: West Spitsbergen Fold Belt and Creataceous opening of the Northeast Atlantic. In Spencer, A. M., Holter, E., Johnsen, S. O., Mørk, A., Nysæther, E., Songstad, P. \&
Spinnangr, $\AA$. (eds) Petroleum Geology of North European Margin, 187-198.

Hazeldine, R. S. 1984: Carboniferous North Atlantic paleogeography: stratigraphic evidence for rifting, not megashear or subduction. Geological Magazine 121,. 443-463.

Heinesen, M. V. 1987: Nedre tertiære basalt breccier og undervands-lavastrømme, sydlige Disko, Vestgrønland: strukturelle, petrografiske og mineralogiske studier. Kbh. universitet. 2 vol. $118 \mathrm{pp}$. Unpublished MSc thesis in Danish.

Hinz, K. 1981: A Hypothesis on Terrestrial Catastrophes. Wedges of very thick Oceanward Dipping Layers beneath Passive Continental Margins. - Their origin and Paleoenvironmental Significance-. Geologisches Jahrbuch 22, 3-28.

Hitchen, K. \& Ritchie, J. D. 1987: Geological review of the West Shetland area. In Brooks, J. \& Glennie, K. (eds) Petroleum Geology of North West Europe, 737-749. Graham \& Trotman, London.

Jones, J. G. 1966: Intraglacial volcanoes of south-west Iceland and their significance in the interpretation of the form of the marine basaltic volcanoes. Nature $212,586-588$.

Jones, E. J. W., Ramsay, A. T. S., Preston, N. J. \& Smith, A. C. S. 1974: A Cretaceous guyot in the Rockall Trough. Nature 251, 129-131.

Jones, J. G. \& Nelson, P. H. H. 1970: The flow of basalt lava from air into water - its structural expression and stratigraphic significance. Geological Magazine 107, 13-19.

Joppen, M. \& White, R. S. 1990: The Structure and Subsidence of Rockall Trough from Two ship Seismic Experiments. Journal of Geophysical Research 9, 19821-19837.

Jørgensen, O. 1984: Zeolite zones in the basaltic lavas of the Faeroe Islands. In Berthelsen, O., Noe-Nygaard, A. \& Rasmussen, J. (eds) The deep drilling project 1980-1981 in the Faeroe Islands, 71-91. Foroya Frodskarfelag.

Kiørboe, L. \& Petersen, S. A. 1992: Seismic investigation of the Faeroe Basalts and their Substratum. Paper presented at "the Tectonics, Sedimentation and Paleoceanography og the North Atlantic Region" Geological Society of London, Edinburgh Meeting 28-29/9, 1992. Abstractbook p. 20. Submitted for publication special publication of the Geological Society.

Laier, T. \& Nytoft, P. 1993a: Biomarkers and isotopes of hydrocarbon traces of the Lopra-1 well. Geological Survey of Denmark, Datareport 3, 1-39 (In danish).

Laier, T. \& Nytoft, P. 1993b: Bitumen coatings on secondary minerals in Tertiary volcanics, Faeroe Islands. In Øygard, $\mathrm{K}$. (ed.) Organic Geochemistry, Poster sessions from 16th international meeting on organic geochemistry, Stavanger, 19-22.

Laughton, A. S., Berggren, W. A. et al. 1972: Deep Sea Drilling Program, Initial Reports 12, 1243 pp.

Lund, J. 1981: Eine Ober-Palaozane Mikroflora von den Faroerne, Danemark. Couier Forschung Institut Senckenberg $50,41-45$.

Lund, J. 1983: Biostratigraphy of interbasaltic coals from the Faeroe Islands. In Bott, M. H. P., Saxov, S., Talwani, M. \& Thiede, J. (eds) Structure and development of the GreenlandScotland Ridge NATO Conference series, Serie IV: Marine Science, 417-423. Plenum Press, New York/London.

Makris, J., Ginzburg, A., Shannon, P. M., Jacob, A. W. B., Bean, C. J. \& Vogt, U. 1991: A new look at the Rockall region offshore Ireland. Marine and Petroleum Geology 8, 410-416.

McKenzie, D. \& Bickle, M. J. 1988: The Volume and Composition of Melt Generated by Extension of the Lithosphere. Journal of Petrology 29, 625-679.

Meincke, J. 1983: The modern current regime across the Greenland-Scotland Ridge. In Bott, M. H. P., Saxov, S., Talwani, M. \& Thiede, J. (eds) Structure and development of the Greenland-Scotland Ridge NATO Conference series, Serie IV: Marine Science, 637-650. Plenum Press, New York/London.

Miller, K. G. \& Tucholke, B. E. 1983: Development of Cenozoic abyssal circulation south of the Greenland-Scotland Ridge. In Bott, M. H. P., Saxov, S., Talwani, M. \& Thiede, J. (eds) Structure and development of the Greenland-Scotland 
Ridge NATO Conference series, Serie IV: Marine Science, 549-589. Plenum Press, New York/London.

Miller, J. A. \& Mathews, D. H. 1973: Rocks of Grenville Age from Rockall Bank. Nature 246, 61 .

Morton, A. C. 1984: Heavy minerals from Paleogene sediments, Deep Sea Drilling Project Leg 81: their bearing on stratigraphy, sediment provenance and the evolution of North Atlantic. In Roberts, D. G. \& Schnitker, D. (eds) Deep Sea Drilling Program. Initial reports 81, 653-661.

Mudge, D. C. \& Rashid, B. 1987: The geology of the Faeroe Basin area. In Brooks, J. \& Glennie, K. (eds) Petroleum Geology of North West Europe, 751-763. Graham \& Trotman, London.

Mutter, J. C. \& Zehnder, C. M. 1988: Deep crustal structure and magmatic processes: the inspection of seafloor spreading in the Norwegian Greenland Sea. In Morton, A. C. \& Parson, L. M. (eds) Early Tertiary Volcanism and the Openeing of the NE Atlantic. Geological Society Special Publication 39, 35-48.

Neish, J. 1993: Seismic structure of the Hatton-Rockall Area: an Integrated Seismic/Modelling Study from Composite Data Sets. In Parker, J. R. (ed.) Petroleum Geology of Northwest Europe: Proceedings of the 4th Conference, 1047-1056.

Nunns, A. G. 1983: Plate tectonic evolution of the GreenlandScotland Ridge and surrounding regions. In Bott, M. H. P., Saxov, S., Talwani, M: \& Thiede, J. (eds) Structure and development of the Greenland-Scotland Ridge NATO Conference series, Serie IV: Marine Science, 11-30. Plenum Press, New York/London.

Pàlmason, G. 1971: Crustal structure of Iceland from Explosion Seismology. Societas Scientiarum Islandica No. 40, $187 \mathrm{pp}$.

Palmasson, G. 1965: Seismic refraction measurements of the basalt lavas of the Faeroe Islands. Tectonophysics 2, 475 482. Rasmussen, J. \& Noe-Nygaard, A. 1969: Beskrivelse til geologisk kort over Færøerne i målestok 1:50 000 (English summary), Danmarks Geologiske Undersøgelse 1 serie 24, $1-370$.

Prægel, N. \& Waagstein, R. 1988: Bundskrabninger ved Færøerne 1987: togtrapport. Geological Survey of Denmark Intern rapport nr. 12.1988, 1-70 in danish with english summary.

Rasmussen, J. \& Noe-Nygaard, A. 1970: Geology of the Faeroe Islands. Danmarks Geologiske Undersøgelse 1. series 25, 142 pp.

Richards, P. C., Ritchie, J. D. \& Thomson, A. R. 1987: Evolution of deep-water climbing dunes in the Rockall Trough implications for overflow currents across the Wyville-Thomson Ridge in the (?) Late Miocene. Marine Geology 76 177-183.

Roberts, D. G. 1975: Marine Geology of the Rockall Plateau and Trough. Royal Astronomical Society, Geophysical Journal 278, 417-509

Roberts, D. G., Ardus, D. A. \& Dearnley, R. 1973: Pre-Cambrian rocks drilled on the Rockall Bank. Nature 244, 21-23.

Roberts, D. G., Bott, M. H. P. \& Urski, C. 1983: Structure and origin of the Wyville-Thomson Ridge. In Bott, M. H. P., Saxov, S., Talwani, M. \& Thiede, J. (eds) Structure and development of the Greenland-Scotland Ridge NATO Conference series, Serie IV: Marine Science, 133-158. Plenum Press, New York/London.

Roberts, D. G., Backman, J. Morton, A., Murry, J. W. \& Keene,
J.B. 1984a: Evolution of Volcanic Rifted Margins: Synthesis of Leg 81 Results on the West Margin of Rockall Plateau. In (Roberts, D. G., Schnitker, D. et al. (eds) Initial Reports of the Deep Sea Drilling Project 81, 883-911.

Roberts, D. G., Morton, A. \& Backman, J. 1984b: Late Paleocene-Eocene Volcanic Events in the northern Atlantic Ocean. In Roberts, D. G., Schnitker, D. et al. (eds) Initial Reports of the Deep Sea Drilling Project 81, 913-923.

Roberts, D. G., Schnitker, D. et al. 1984: Initial reports of the DSDP leg 81 .

Roberts, D. G., Ginzburg, A., Nunn, K. \& McQuillin, R. 1988: The structure of the Rockall Trough from seismic refraction and wide angle reflection measurements. Nature 322, 632635.

Scrutton. R. A. 1972: Crustal structure of the Rockall Plateau microcontinent. Royal Astronomical Society, geophysical Journal 27, 259-275.

Skogseid, J. \& Eldholm, O. 1988: Early Cainozoic evolution of the Norwegian volcanic passive margin and the formation of marginal highs. In: Morton, A. C. \& Parson, L. M. (eds) Early tertiary Volcanism and the Opening of the NE Atlantic. Geological Society Special Publication 39, 49-58.

Smythe, D. K. 1983: Faeroe-Shetland Escarpment and Continental margin north of the faeroes. In Bott, M. H. P., Saxov, S., Talwani, M. \& Thiede, J. (eds) Structure and development of the Greenland-Scotland Ridge NATO Conference series, Serie IV: Marine Science 109-119. Plenum Press New York' London. 109-120

Spence, G. D., White, R. S., Westbrook, G. K. \& Fowler, S. R. 1989: The Hatton Bank Continental Margin; I, shallow structure from two-ship expanding spread profiles. The Geophysical Journal of Royal Astronomical Society 96, 273-294.

Talwani, M., Mutter, J. \& Hinz, J. 1983: Ocean continent boundary under the Norwegian continental margin. In Bott, $\mathbf{M}$. $\mathbf{H}$. P., Saxov, S., Talwani, M. \& Thiede, J. (eds) Structure and development of the Greenland-Scotland Ridge NATO Conference series, Serie IV: Marine Science, 121-131. Plenum Press New York/London.

Waagstein, R. 1988: Structure, composition and age of the Faeroe basalt plateau. In: Morton, A. C: \& Parson, L. M. (eds) Early tertiary Volcanism and the Opening of the NE Atlantic. Geological Society Special Publication 39, 225-238.

White, R. S. 1988: A hot-spot model for the early tertiary volcanism in the North Atlantic. In: Morton, A. C: \& Parson, L. M. (eds) Early tertiary Volcanism and the Opening of the NE Atlantic. Geological Society Special Publication 39 3-13.

White, R. S., Spence, G. D., Fowler, S. R., McKenzie, D. P. Westbrook, G. K. \& Bowen, A. N. 1987: Magmatism at rifted continental margins. Nature 330, 439-444.

Wood, M. V., Hall, J. \& van Horn, B. 1987: Post-Mesozoic differential subsidence in the north-east Rockall Trough related to volcanicity and sedimentation. In Brooks, J. \& Glennie, K. (eds) Petroleum Geology of Northe West Europe, $677-685$.

Wood, M. V., Hall, J. \& Doody, J. J. 1988: Distribution of early Tertiary lavas in the NE Rockall Trough. In Morton, A. C: \& Parson, L. M. (eds) Early tertiary Volcanism and the Opening of the NE Atlantic. Geological Society Special Publication 39, 283-292. 